January 2003 • NREL/TP-550-31976

\title{
Non-Technical Barriers to the Commercialization of PV Power Systems in the Built Environment
}

P. Eiffert

Imaginlt LLC

International Energy Agency PVPS Task 7: Photovoltaic Power Systems in the Built Environment

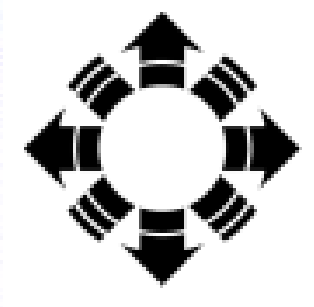

\section{NPEI}

National Renewable Energy Laboratory

1617 Cole Boulevard

Golden, Colorado 80401-3393

NREL is a U.S. Department of Energy Laboratory

Operated by Midwest Research Institute $\bullet$ Battelle $\bullet$ Bechtel

Contract No. DE-AC36-99-G010337 


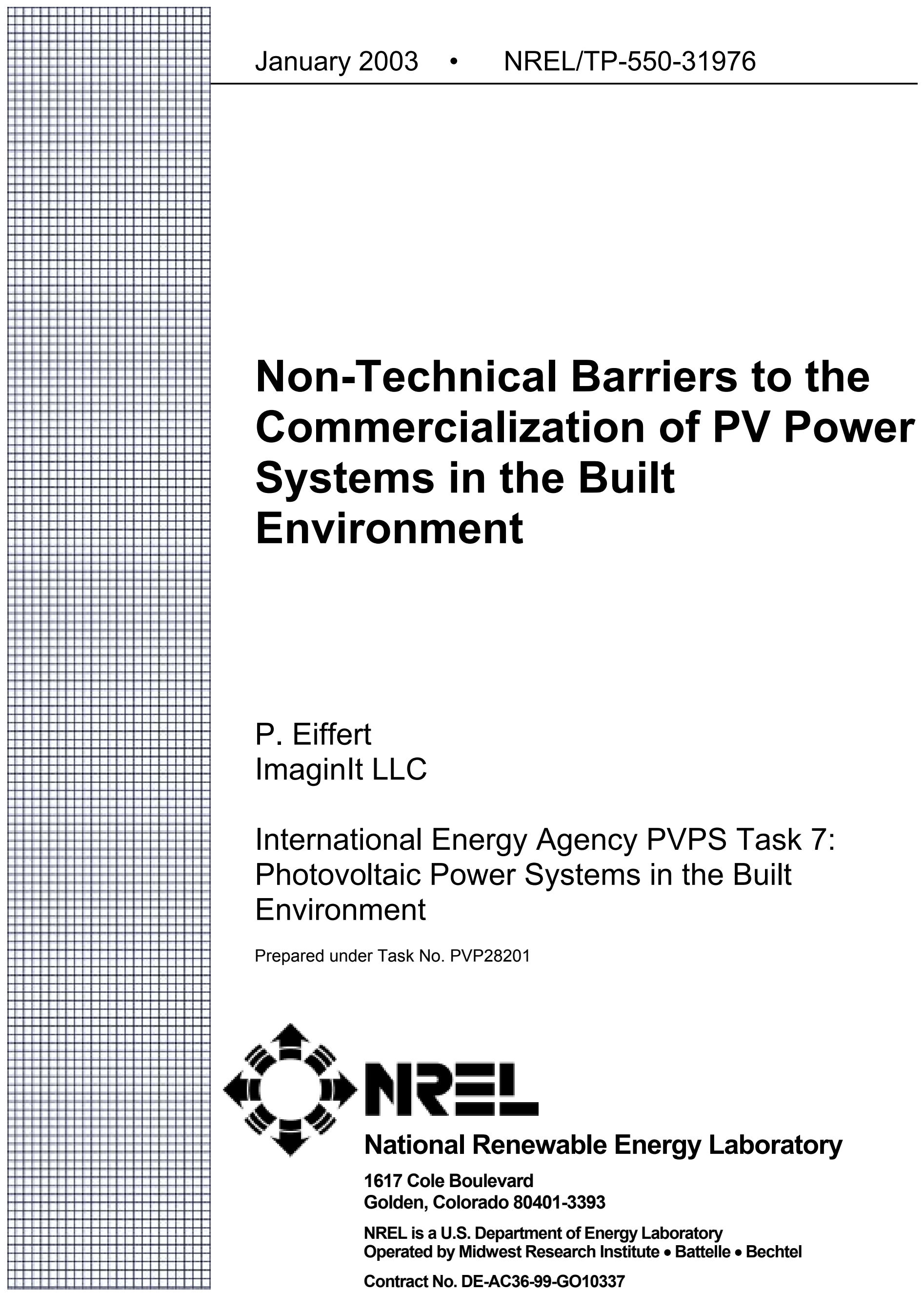




\section{NOTICE}

This report was prepared as an account of work sponsored by an agency of the United States government. Neither the United States government nor any agency thereof, nor any of their employees, makes any warranty, express or implied, or assumes any legal liability or responsibility for the accuracy, completeness, or usefulness of any information, apparatus, product, or process disclosed, or represents that its use would not infringe privately owned rights. Reference herein to any specific commercial product, process, or service by trade name, trademark, manufacturer, or otherwise does not necessarily constitute or imply its endorsement, recommendation, or favoring by the United States government or any agency thereof. The views and opinions of authors expressed herein do not necessarily state or reflect those of the United States government or any agency thereof.

Available electronically at http://www.osti.gov/bridge

Available for a processing fee to U.S. Department of Energy and its contractors, in paper, from:

U.S. Department of Energy

Office of Scientific and Technical Information

P.O. Box 62

Oak Ridge, TN 37831-0062

phone: 865.576 .8401

fax: 865.576.5728

email: reports@adonis.osti.gov

Available for sale to the public, in paper, from:

U.S. Department of Commerce

National Technical Information Service

5285 Port Royal Road

Springfield, VA 22161

phone: 800.553.6847

fax: 703.605.6900

email: orders@ntis.fedworld.gov

online ordering: http://www.ntis.gov/ordering.htm 


\section{Foreword}

The International Energy Agency (IEA), founded in November 1974, is an autonomous body within the framework of the Organisation for Economic Co-operation and Development (OECD), which carries out a comprehensive program of energy cooperation among its 23 member countries. The European Commission also participates in this work.

The IEA Photovoltaic Power Systems Programme (PVPS) is a collaborative R\&D agreement. Since 1993, its participants have conducted a variety of joint projects concerned with converting photovoltaic (PV) solar energy into electricity. An executive committee composed of one representative from each participating country heads the program. Operating agents manage individual research projects (Tasks), and activities are underway in seven Tasks.

The 21 members of IEA PVPS are Australia, Austria, Canada, Denmark, European Commission, Finland, France, Germany, Israel, Italy, Japan, Korea, Mexico, the Netherlands, Norway, Portugal, Spain, Sweden, Switzerland, United Kingdom, and the United States.

Task 7 focuses on building-integrated PV, linking developments in IEA countries. Its overall objective is to enhance the economic viability and architectural and technical quality of PV power systems in the built environment and to assess and remove non-technical barriers for their introduction as energy-significant options. Task 7 began in January 1997, building on previous IEA collaborative actions (Task 16 of the Solar Heating and Cooling Program).

Task 7 focuses primarily on integrating PV into the architectural designs of roofs and facades for all types of buildings and other structures (such as noise barriers) in the built environment. Task 7 motivates the collaboration among urban planners, architects, building engineers, PV system specialists, utility specialists, the PV and building industry, and other professionals involved in PV.

More information on task activities and results is available at http://www.task7.org/ or http://www.ieapvps.org/.

This report was prepared under the supervision of PVPS Task 7 by Patrina Eiffert, Ph.D., director of ImaginIt LLC USA, in cooperation with Australia, Austria, Canada, Switzerland, Denmark, Germany, Finland, Italy, Japan, the Netherlands, Spain, Sweden, Great Britain, and the United States, and approved by the PVPS Programme Executive Committee. The report expresses, as nearly as possible, an international consensus of the opinions on the subject. 


\section{Acknowledgments}

This research is based on a five-year effort within the IEA PVPV Task 7: Photovoltaic Power Systems in the Built Environment. The information presented is extracted from reports completed under this international effort, including:

Eiffert, P.; Leonard, G.; Thompson, A. (2002). Guidelines for the Economic Evaluation of BuildingIntegrated Photovoltaic Power Systems (NREL/TP-550-31977), National Renewable Energy Laboratory, Golden, CO, USA.

Haas, R. (2002). Market Deployment Strategies for PV Systems in the Built Environment, An Evaluation of Incentives, Support Programmes and Marketing Activities (IEA PVPS T7-6: 2002), Institute of Energy Economics, Vienna University of Technology. Vienna, Austria.

Mierlo, B. van; Oudshoff, B. (1999). Literature Survey and Analysis of Non-Technical Problems for the Introduction of Building Integrated Photovoltaic Systems (IEA PVPS T7-1 1999), IVAM environmental research, Universiteit van Amsterdam. Amsterdam, the Netherlands.

Nowak, S.; Gutschner, M.; Toggweiler, P.; Ruoss, D. (2002). Potential for Building Integrated Photovoltaics - Achievable Levels of Electricity from Photovoltaic Roofs and Facades: Methodology, Case Studies, Rules of Thumb, and Determination of the Potential of Building Integrated Photovoltaics for Selected Countries (IEA PVPS T7-4 2002), NET Nowak Energy \& Technology, Ltd., St. Ursine, Switzerland; Enecolo Ltd., Mönchaltorf, Switzerland. 


\section{Table of Contents}

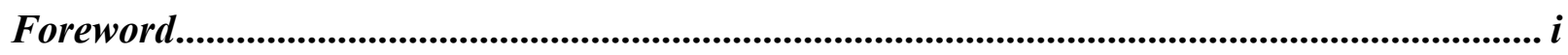

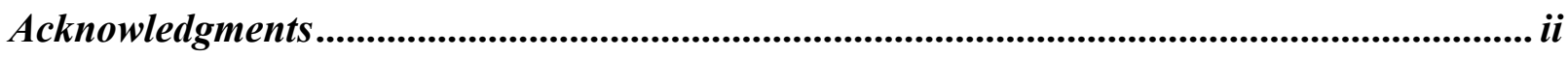

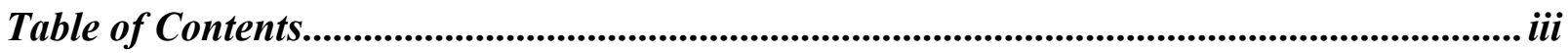

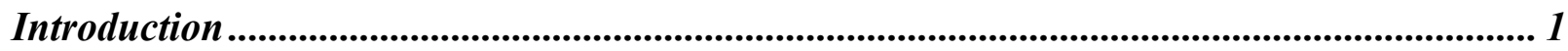

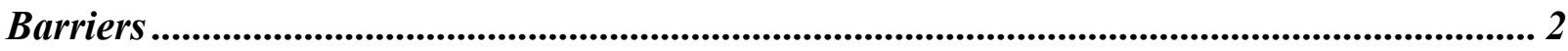

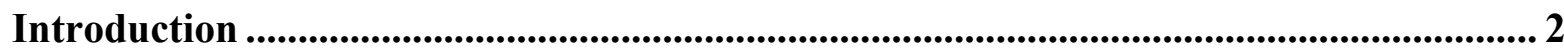

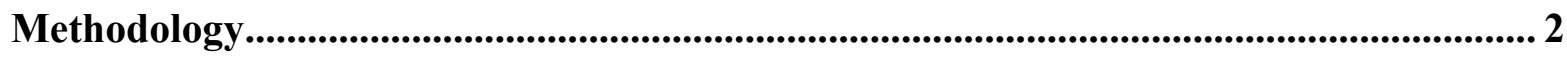

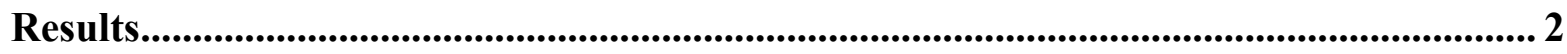

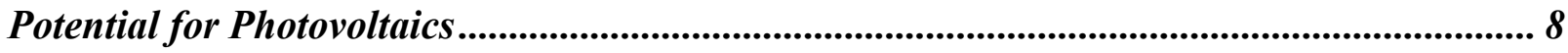

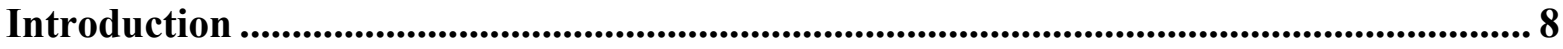

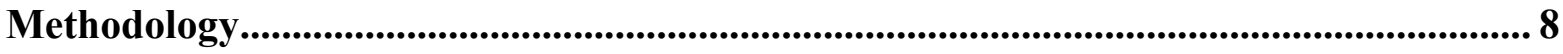

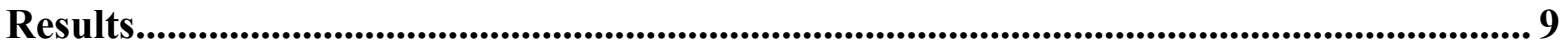

Conclusions ......................................................................................................................... 11

Economic Considerations and Guidelines ............................................................... 12

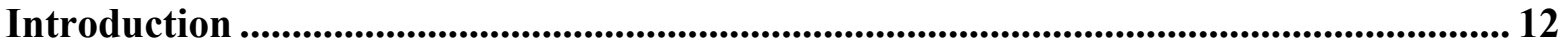

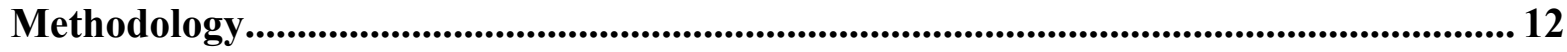

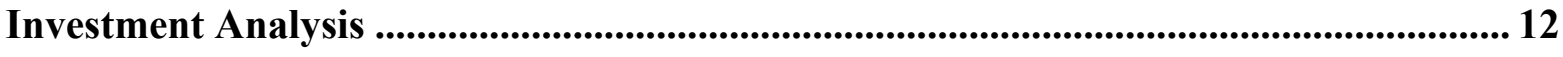

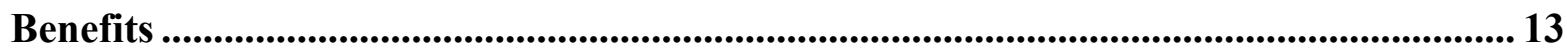

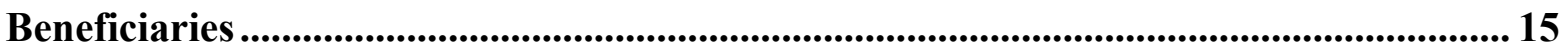

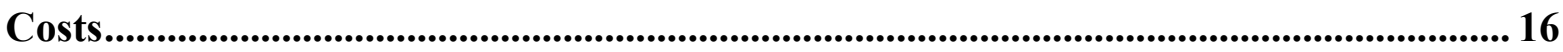

Market Strategies............................................................................................................ 18

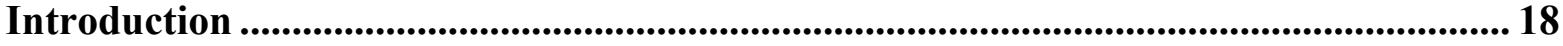

Methodology ...................................................................................................................... 19

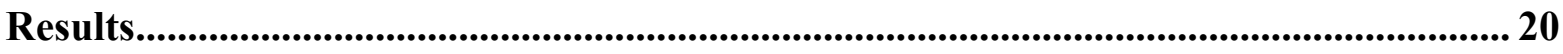

Evaluation of National Programs ................................................................................ 24

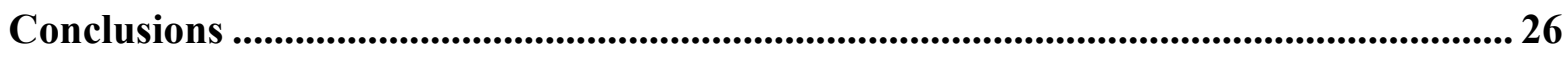

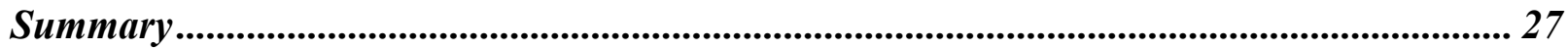




\section{Introduction}

Building-integrated photovoltaics (BIPV) requires institutional support to become a viable technology and a sustainable solution. Between 1990 and 2000, the solar industry demonstrated the viability of BIPV technology by installing hundreds of thousands of successful systems around the world. Architects have created award-winning, elegant solar buildings. Utility companies and municipalities have adopted this technology to augment their infrastructure and electricity services network. The potential for BIPV is widely recognized as significant; however, institutional barriers can slow its deployment.

Our research emphasizes institutional issues related to introducing and commercializing photovoltaic (PV) power systems in the built environment. This overview includes:

- An assessment of barriers in the marketplace

- The potential for PV in the built environment

- The determination of the value and economic considerations and guidelines

- An overview of current international market strategies.

Each step is based on extensive surveys performed under the authority of the International Energy Agency (IEA) Photovoltaic Power Systems Programme (PVPS) Task 7.

The objectives of Task 7 are:

- Enhance the architectural and technical quality of PV in the built environment

- Enhance the economic viability of PV systems in the built environment

- Assess non-technical barriers

- Remove non-technical barriers so that PV systems can be introduced as energy-significant options. 


\section{Barriers}

\section{Introduction}

PV power systems face a number of barriers to the mainstream energy and building markets: high capital costs and associated financing, administration, architecture, communication, marketing, and environment. Some barriers can be overcome by assessing the energy and nonenergy benefits of a PV power system, thus making it a cost-effective option even with current costs and energy prices.

\section{Methodology}

A literature search was performed from which overall characteristics of relevant literature are derived. The data of the screened literature were collected in a database and characterized by source, country, main and minor encountered problems, validity, barriers, and solutions.

The barriers for introducing PV were grouped, summarized, and described in the database. Six problem categories were distinguished: financing, administration, architecture, communication, marketing, and environment.

These problem categories are often related to the following six groups involved in the introduction of BIPV:

1. PV industry: parties developing, producing, and supplying (parts of) PV systems

2. Building sector: especially architects, but also project developers, building contractors, etc.

3. Energy sector: mainly utilities; also companies producing electricity

4. Public: the general public, people living or working in PV buildings, people living near PV buildings, and people buying PV/green electricity

5. Government: national government and local authorities

6. Financial sector: banks and insurance companies

\section{Results}

The problems and potential solutions are summarized in Table 1. They are categorized by the target groups that deal with these problems.

PV systems for the built environment include many different and relatively new products, so many subjects are worth investigating further. Also, the problem areas call for further research. The most important blanks in our knowledge of barriers and strategies to a widespread introduction of BIPV are listed below, focused on research among target groups. 
Table 1: Implementing BIPV: Problems and Potential Solutions (Mierlo, et al., 1999)

\section{Problem Category Problems $\rightarrow$ \\ Potential Solutions}

\begin{tabular}{|c|c|c|c|c|c|c|}
\hline $\begin{array}{l}\text { Problem } \\
\text { Category }\end{array}$ & PV Industry & Building Sector & Energy Sector & Public & Government & Financial Sector \\
\hline Financing: costs & $\begin{array}{l}\text { production, } \\
\text { installation, and BOS } \\
\text { costs are high } \rightarrow \\
\text { prefab systems and } \\
\text { standardization, } \\
\text { lowering overhead } \\
\text { and labor costs, } \\
\text { prolonging lifetime } \\
\text { bigger market } \\
\text { needed } \rightarrow \text { more } \\
\text { export } \\
\end{array}$ & & $\begin{array}{l}\text { considers PV prices } \\
\text { too high } \rightarrow \text { consider } \\
\text { network costs; } \\
\text { develop techniques } \\
\text { to model costs and } \\
\text { benefits, e.g., life } \\
\text { cycle costing }\end{array}$ & $\begin{array}{l}\text { cost gap between PV } \\
\text { costs and acceptable } \\
\text { market price } \rightarrow \text { make } \\
\text { use of willingness to } \\
\text { pay; lower costs by } \\
\text { bulk purchase or } \\
\text { integration of PV in } \\
\text { buildings }\end{array}$ & $\begin{array}{l}\text { PV not competitive } \\
\text { with fossil fuels } \rightarrow \\
\text { internalization of } \\
\text { external costs by } \\
\text { creating quantitative } \\
\text { values, subsidies, or } \\
\text { tax benefits; } \\
\text { legislation for higher } \\
\text { rates; stimulating } \\
\text { export to developing } \\
\text { countries }\end{array}$ & \\
\hline $\begin{array}{l}\text { Financing: } \\
\text { investments }\end{array}$ & $\begin{array}{l}\text { Few investments } \\
\text { because profits are } \\
\text { small } \rightarrow \text { developing } \\
\text { financing schemes; } \\
\text { export and niche } \\
\text { markets }\end{array}$ & & & & & $\begin{array}{l}\text { no willingness to } \\
\text { invest because of } \\
\text { perceived high risks } \\
\rightarrow \text { a dissemination } \\
\text { strategy from the } \\
\text { industry, government } \\
\text { support }\end{array}$ \\
\hline $\begin{array}{l}\text { Administration: } \\
\text { financial } \\
\text { instruments }\end{array}$ & $\begin{array}{l}\text { no steady demand } \\
\text { because of unstable } \\
\text { policy } \rightarrow \text { long-term } \\
\text { stable policy }\end{array}$ & & $\begin{array}{l}\text { rate-based incentives } \\
\text { under pressure by } \\
\text { deregulation of the } \\
\text { electricity market } \rightarrow \\
\text { national policy } \\
\text { green pricing is } \\
\text { turning a social } \\
\text { problem into an } \\
\text { individual one }\end{array}$ & $\begin{array}{l}\text { subsidy procedures } \\
\text { slow and variable } \rightarrow \\
\text { a simple subsidy } \\
\text { arrangement } \\
\text { tariffs for RE- } \\
\text { electricity too low and } \\
\text { variable } \rightarrow \text { cost- } \\
\text { effective fixed rates, } \\
\text { more realistic } \\
\text { calculation method }\end{array}$ & & \\
\hline
\end{tabular}




\begin{tabular}{|c|c|c|c|c|c|}
\hline $\begin{array}{l}\text { Problem } \\
\text { Category }\end{array}$ & PV Industry Building Sector & Energy Sector & Public & Government & Financial Sector \\
\hline $\begin{array}{l}\text { Administration: } \\
\text { organization }\end{array}$ & & $\begin{array}{l}\text { central organization } \\
\text { and energy } \\
\text { production } \rightarrow \text { more } \\
\text { decentralized } \\
\text { organization } \\
\text { - } \text { planning and } \\
\text { selection tools } \\
\text { inadequate for } \\
\text { valuing PV } \rightarrow \\
\text { adjusting tools } \\
\text { not enough customer } \\
\text { orientation } \rightarrow \text { follow } \\
\text { strategies to interest } \\
\text { customers in PV }\end{array}$ & & $\begin{array}{l}\text { - because of } \\
\text { liberalization, utilities } \\
\text { will turn to cheaper } \\
\text { and less risky options } \\
\rightarrow \text { an obligated share } \\
\text { of PV using tradable } \\
\text { emission credits or } \\
\text { green labeling } \\
\text { public policy on a } \\
\text { fossil-fuel-based } \\
\text { economy } \rightarrow \text { choosing } \\
\text { for a sustainable } \\
\text { future, internalizing } \\
\text { external costs, taxing } \\
\text { fossil fuels } \\
\text { RE policy not } \\
\text { integrated at local } \\
\text { level } \rightarrow \text { local energy } \\
\text { plans (agenda 21) }\end{array}$ & \\
\hline $\begin{array}{l}\text { Administration: } \\
\text { legislation and } \\
\text { regulation }\end{array}$ & & 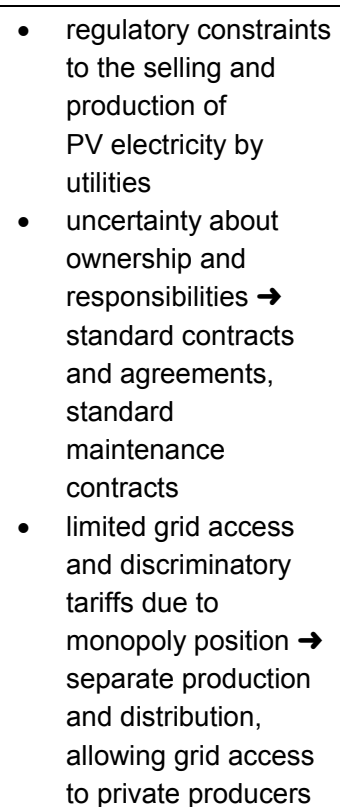 & $\begin{array}{l}\text { - procedure for permits } \\
\text { for BIPV unclear and } \\
\text { slow } \\
\text { planning procedures } \\
\text { or building codes } \\
\text { form constraints } \\
\text { uncertainty on liability } \\
\rightarrow \text { standard contracts, } \\
\text { warranties }\end{array}$ & $\begin{array}{l}\text { - lack of appropriate } \\
\text { national legal } \\
\text { framework and } \\
\text { economic regulations } \\
\rightarrow \text { long-term strategy, } \\
\text { changing legal and } \\
\text { institutional } \\
\text { framework, PV } \\
\text { mandatory for } \\
\text { buildings and schools } \\
\text { lack of regulations for } \\
\text { shadow hindrance } \\
\text { international lack of } \\
\text { regulations to } \\
\text { promote PV } \rightarrow \text { legal } \\
\text { and regulatory } \\
\text { framework }\end{array}$ & \\
\hline
\end{tabular}




\begin{tabular}{|c|c|c|c|c|c|}
\hline $\begin{array}{l}\text { Problem } \\
\text { Category }\end{array}$ & PV Industry & Building Sector & Energy Sector & Government & Financial Sector \\
\hline $\begin{array}{l}\text { Architecture: } \\
\text { design }\end{array}$ & & $\begin{array}{l}\text { - } \begin{array}{l}\text { PV systems not fit for } \\
\text { buildings } \rightarrow \mathrm{PV}\end{array} \\
\text { product development } \\
\text { meeting requirements } \\
\text { of building elements } \\
\text { - } \quad \text { optimal installation } \\
\text { PV not compatible } \\
\text { with buildings } \rightarrow \text { early } \\
\text { involvement of } \\
\text { architects } \\
\text { limited colors and } \\
\text { sizes } \rightarrow \text { wider range } \\
\text { of colors and sizes }\end{array}$ & & $\begin{array}{ll}\text { - } & \text { visual hinderance } \rightarrow \\
\text { architectural } \\
\text { integration of PV in } \\
\text { buildings } \\
\text { - } \\
\text { low overall } \\
\text { acceptance of PV } \rightarrow \\
\text { research on relation } \\
\text { between opinion on } \\
\text { aesthetics and PV } \\
\text { acceptance } \\
\text { theft, vandalism in } \\
\text { public places }\end{array}$ & \\
\hline $\begin{array}{l}\text { Architecture: } \\
\text { standards }\end{array}$ & $\begin{array}{l}\text { lack of guidelines for } \\
\text { producing, installing } \\
\text { etc. } \rightarrow \text { internationally } \\
\text { agreed standards, } \\
\text { certification of BIPV } \\
\text { products }\end{array}$ & $\begin{array}{l}\text { PV systems do not } \\
\text { meet requirements of } \\
\text { building elements } \rightarrow \\
\text { certification of BIPV } \\
\text { products }\end{array}$ & $\begin{array}{l}\text { high costs and } \\
\text { uncertainty by lack of } \\
\text { standards } \rightarrow \\
\text { certification of BIPV, } \\
\text { internationally agreed } \\
\text { electrotechnical } \\
\text { standards } \\
\end{array}$ & & \\
\hline $\begin{array}{l}\text { Communication: } \\
\text { needs for } \\
\text { information }\end{array}$ & & $\begin{array}{l}\text { - } \text { no innovative attitude } \\
\text { lack of awareness of } \\
\mathrm{PV} \rightarrow \text { appropriate } \\
\text { design tools, better } \\
\text { information on } \mathrm{PV} \\
\text { products, education }\end{array}$ & $\begin{array}{l}\text { lack of experience } \\
\text { and knowledge on } \\
\mathrm{PV} \text { technology, the } \\
\text { markets, and the } \\
\text { building sector } \rightarrow \\
\text { more info, gaining } \\
\text { and exchanging } \\
\text { experience } \\
\text { negative attitude } \rightarrow \\
\text { greenhouse gas } \\
\text { emission targets, } \\
\text { more information } \\
\text { exchange }\end{array}$ & $\begin{array}{ll}\text { - } & \text { distrust toward } \\
\text { planners } \rightarrow \\
\text { developing local } \\
\text { guidelines and } \\
\text { involving local people } \\
\text { lack of info and } \\
\text { awareness } \rightarrow \\
\text { distinguishing target } \\
\text { groups, info geared } \\
\text { toward their needs } \\
\text { and interests }\end{array}$ & $\begin{array}{l}\text { lack of confidence } \\
\text { and awareness } \rightarrow \\
\text { dissemination } \\
\text { strategy toward } \\
\text { banks and insurance } \\
\text { companies, } \\
\text { developing financial } \\
\text { models }\end{array}$ \\
\hline $\begin{array}{l}\text { Communication: } \\
\text { supply of } \\
\text { information }\end{array}$ & & $\begin{array}{l}\text { supply of information } \\
\text { inappropriate } \rightarrow \\
\text { presenting } \\
\text { information in format } \\
\text { and carriers that } \\
\text { architects use } \\
\text { - supply insufficient } \rightarrow \\
\text { information on details } \\
\text { of PV products } \\
\end{array}$ & & $\begin{array}{l}\text { no reliable, } \\
\text { independent info } \\
\text { source } \rightarrow \text { info } \\
\text { through normally } \\
\text { used channels, } \\
\text { providing } \\
\text { independent sources } \\
\text { from which the public } \\
\text { can get more info } \\
\end{array}$ & \\
\hline
\end{tabular}




\begin{tabular}{|c|c|c|c|c|c|}
\hline $\begin{array}{l}\text { Problem } \\
\text { Category }\end{array}$ & Building Sector & Energy Sector & Public & Government & Financial Sector \\
\hline $\begin{array}{l}\text { Marketing: } \\
\text { potential markets }\end{array}$ & $\begin{array}{l}\text { inadequate } \\
\text { understanding of the } \\
\text { utility and other } \\
\text { markets } \rightarrow \text { analyzing } \\
\text { market, developing } \\
\text { marketing strategy } \\
\end{array}$ & $\begin{array}{l}\text { inadequate } \\
\text { understanding of their } \\
\text { customers and their } \\
\text { valuing of PV } \rightarrow \\
\text { marketing strategy, } \\
\text { arrange PV offerings }\end{array}$ & & & \\
\hline $\begin{array}{l}\text { Marketing: } \\
\text { reaching the } \\
\text { market }\end{array}$ & $\begin{array}{l}\text { lack of trust among } \\
\text { customers because } \\
\text { of absence of } \\
\text { business plans } \\
\text { PV products unclear } \\
\text { to customers } \rightarrow \\
\text { promote and } \\
\text { distribute products } \\
\text { that satisfy demands }\end{array}$ & $\begin{array}{l}\text { not customer- } \\
\text { oriented, no } \\
\text { knowledge of } \\
\text { purchasing decisions } \\
\rightarrow \text { promote and } \\
\text { distribute wanted PV } \\
\text { products, guarantees, } \\
\text { and service } \\
\text { public skeptical about } \\
\text { motives of utilities to } \\
\text { sell PV products } \\
\end{array}$ & & & \\
\hline $\begin{array}{l}\text { Marketing: } \\
\text { infrastructure }\end{array}$ & & $\begin{array}{l}\text { - lack of utility-related } \\
\text { distribution channels } \\
\text { - lack of product } \\
\text { catalogs for utilities } \\
\text { - lack of services such } \\
\text { as maintenance } \rightarrow \\
\text { after-sales support }\end{array}$ & $\begin{array}{l}\text { lack of installation } \\
\text { and maintenance } \\
\text { service } \rightarrow \text { after-sales } \\
\text { support } \\
\text { no way to assess the } \\
\text { quality of suppliers } \rightarrow \\
\text { certification }\end{array}$ & & \\
\hline Environment & $\begin{array}{ll}\text { - } & \text { high energy use at } \\
\text { production } \rightarrow \\
\text { recycling, BIPV, } \\
\text { energy-efficient } \\
\text { production } \\
\text { - } \quad \text { resource depletion } \\
\text { - } \quad \text { toxic and hazardous } \\
\text { materials } \rightarrow \text { research } \\
\text { on safer materials } \\
\text { - } \quad \text { waste } \rightarrow \text { recycling } \\
\end{array}$ & & & $\begin{array}{ll} & \text { high energy use at } \\
\text { production } \rightarrow \\
\text { recycling, BIPV, } \\
\text { energy-efficient } \\
\text { production } \\
\text { - } \quad \text { resource depletion } \\
\text { - } \text { toxic and hazardous } \\
\text { materials } \rightarrow \text { research } \\
\text { on safer materials } \\
\text { - } \quad \text { waste } \rightarrow \text { recycling } \\
\end{array}$ & \\
\hline
\end{tabular}




\section{Photovoltaic Industry}

- Research the PV industry's willingness to invest in market studies and product development

- Investigate expected technical developments that could change or create new markets

- Check knowledge on requirements of building elements and the consequences for BIPV systems

- Assess the attitude toward certification and standardization and willingness to pay (WTP)

- Assess the attitude toward and possibilities for recycling, waste problems, and using other materials.

\section{Building Sector}

- Investigate desirable product developments for several PV applications in the built environment

- Research the preconditions for project developers to invest.

\section{Energy Sector}

- Measure the acceptance of PV, PV policy, and the influence of deregulation to learn why some utilities are ahead or behind in introducing PV and to judge their future role when the market expands

- Determine whether utilities are willing and able to implement planning and cost calculation methods that value PV more

- Conduct market research to assess utilities' interests and demands.

\section{Public}

- Study the knowledge on PV and needs for information of the public and specific groups to address information campaigns

- Study prerequisites for the WTP for BIPV to support the design of successful PV products and effective delivery schemes

- Investigate the effects of PV on overall energy consumption to prevent increasing consumption and the ways to manage and change the direct use of PV electricity to enhance the value of PV for load management

- Research opinions on the aesthetics of BIPV and the relation with overall acceptance of PV.

\section{Government}

- Investigate the possibilities and constraints to change national and international policies

- Study the acceptance of PV and the local authorities' knowledge of PV. Determine their willingness to create preconditions and remove regulations that hinder the application or an optimal yield of PV systems in their municipalities.

\section{Financial Sector}

- Conducting research among financial institutions about PV does not seem valuable because they have limited experience with PV. It could be worthwhile to learn how financial institutions usually "open up" for new technologies comparable to PV and under which conditions they are willing to invest or insure. 


\section{Other Potential Photovoltaic Consumers}

- Assess the market among small- and medium-size enterprises, industries, and nonprofit organizations.

\section{Potential for Photovoltaics}

\section{Introduction}

The development of sound PV market introduction policies depends on knowledge of its achievable contributions to renewable energy portfolios, given the availability of building surfaces. An assessment of the potential for BIPV applications and opportunities requires an analysis of the building stock with respect to suitability for BIPV deployment. Some building surfaces have technical limitations; others have limited capabilities to generate PV power because of poor orientation, inclination, or shading effects. Accurate BIPV potential studies are necessary to evaluate the market potential and the target and focus groups; to assist the PV industry, the building sector, utilities, and energy policy makers (with respect to BIPV products); and to provide information to planners and lawmakers.

\section{Methodology}

The objectives of this study are to:

- Assess and compare approaches, potential estimates, and case studies

- Formulate an accepted and validated methodology

- Develop a comprehensive set of rules and calculate the potential of BIPV.

The BIPV potential calculations and estimates lead to a number of findings that are useful to incorporate in future PV roadmaps.

An assessment of the BIPV potential starts with a determination of the total roof and facade area, which is subsequently corrected for architectural suitability. Few countries and regions have direct statistical information concerning roof and facade areas. The BIPV potential calculations in this report are based on ground floor area figures, which are transformed into roof and facade surface figures. The BIPV potential can then be calculated by applying factors for solar yield and architectural suitability to the gross roof and facade surfaces.

Architectural suitability includes corrections for limitations that result from construction (HVAC installations, elevators, terraces, etc.), historical considerations, shading effects, and use of the available surfaces for other purposes. It takes into account the relative amount of irradiation for the surfaces depending on their orientation, inclination, and location, as well as the potential performance of the PV system integrated in the building. Solar-architectural suitability is expressed in relative terms and results in utilization factors that reflect the BIPV potential in most significant relative terms. To extract absolute figures in square meters and kilowatt-hours, the relative figures must be combined with the building areas and available solar irradiation. 


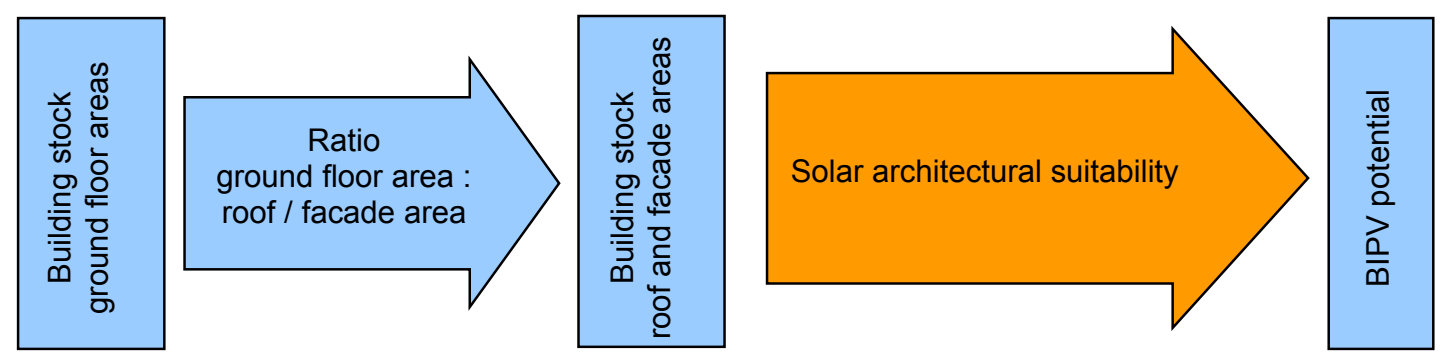

Figure 1: Most significant terms and factors for the BIPV potential (Nowak et al. 2002).

Factors for moving from ground floor area to roof and facade surface area, as well as for solar and architectural suitability, can be derived by analyzing representative samples with a limited number of buildings and sections of a particular building stock and then upscaling the results to the overall building stock. Following this, sufficient data and methodological knowledge are available to derive some general factors for calculating the BIPV potential.

By linking the average figures of area per capita suitable for solar architecture to country-specific features (mainly population size and annual solar irradiation), the solar electricity potential can be calculated.

\begin{tabular}{|c|c|c|c|c|c|c|c|}
\hline $\begin{array}{l}\text { Production of solar } \\
\text { electricity }\end{array}$ & $=$ & $\begin{array}{l}\text { Available area per } \\
\text { capita }\end{array}$ & $* \begin{array}{l}\text { Population } \\
\text { size }\end{array}$ & $* \begin{array}{l}\text { Utilization } \\
\text { factor }\end{array}$ & $* \begin{array}{l}\text { Solar } \\
\text { yield }\end{array}$ & $* \begin{array}{l}\begin{array}{l}\text { Solar } \\
\text { irradiation }\end{array} \\
\end{array}$ & $* \begin{array}{l}\text { Global conversion } \\
\text { efficiency }\end{array}$ \\
\hline
\end{tabular}

\section{Figure 2: Calculation scheme for the production of BIPV solar electricity.}

More precisely, the formula ingredients are:

- Building type: residential, agriculture (primary sector), industry (secondary sector), commercial (tertiary sector), other, and total (all building stock)

- Available area per capita: average figures and standards. The values are given in square meters.

- Population size: number of people (in millions) living in the country

- Utilization factor (suitability in relative terms) of 0.4 for roofs and 0.15 for facades*

- Solar yield: weighted average relative yield of good areas per geographical unit (here: countries)

- Solar irradiation: country-specific weighted value for the maximum annual solar input in $\mathrm{kWh} / \mathrm{yr} / \mathrm{m}^{2}$

- Global conversion efficiency: ratio of "electricity output/solar irradiation" (simplified ratio: generally $10 \%$ )

- Production of solar electricity: product of the factors described above in $\mathrm{TWh} / \mathrm{y}$.

\section{Results}

The building types can be further differentiated. Applying this calculation scheme leads to the following figures for the solar electric BIPV potential (see Table 2 and Figure 3). 
Table 2: BIPV Area Potential for Roofs and Areas of Selected IEA Countries (Nowak, et al. 2002)

\begin{tabular}{|c|c|c|c|c|c|c|c|}
\hline $\begin{array}{l}\text { BIPV area potential } \\
\text { (in } \mathrm{km}^{2} \text { ) }\end{array}$ & & $\begin{array}{l}\text { Residential } \\
\text { buildings }\end{array}$ & $\begin{array}{l}\text { Agricultural } \\
\text { buildings }\end{array}$ & $\begin{array}{l}\text { Industrial } \\
\text { buildings }\end{array}$ & $\begin{array}{l}\text { Commercial } \\
\text { buildings }\end{array}$ & $\begin{array}{l}\text { Other } \\
\text { buildings }\end{array}$ & All buildings \\
\hline Australia & Roof & 373.50 & 22.50 & 6.00 & 16.5 & 3.75 & 422.25 \\
\hline 96 & Facade & 140.06 & 2.81 & 2.25 & 8.25 & 1.41 & 158.34 \\
\hline \multirow[t]{2}{*}{ Austria } & Roof & 85.65 & 17.13 & 15.19 & 17.45 & 4.20 & 139.62 \\
\hline & Facade & 32.12 & 2.14 & 5.70 & 8.73 & 1.58 & 52.36 \\
\hline \multirow{2}{*}{ Canada } & Roof & 727.20 & 36.36 & 60.60 & 133.32 & 6.06 & 963.54 \\
\hline & Facade & 272.70 & 4.55 & 22.73 & 66.66 & 2.72 & 361.33 \\
\hline \multirow[t]{2}{*}{ Denmark } & Roof & 50.88 & 14.84 & 10.60 & 10.60 & 1.06 & 87.98 \\
\hline & Facade & 19.08 & 1.86 & 3.98 & 5.30 & 0.40 & 32.99 \\
\hline \multirow[t]{2}{*}{ Finland } & Roof & 78.28 & 21.01 & 19.16 & 8.45 & 0.41 & 127.31 \\
\hline & Facade & 19.08 & 1.86 & 3.98 & 5.30 & 0.40 & 32.99 \\
\hline \multirow[t]{2}{*}{ Germany } & Roof & 721.78 & 164.04 & 229.66 & 164.04 & 16.40 & 1295.92 \\
\hline & Facade & 270.67 & 20.51 & 86.12 & 82.02 & 6.15 & 485.97 \\
\hline \multirow[t]{2}{*}{ Italy } & Roof & 410.26 & 113.96 & 136.75 & 91.17 & 11.40 & 763.53 \\
\hline & Facade & 153.85 & 14.25 & 51.28 & 45.58 & 4.27 & 286.32 \\
\hline \multirow[t]{2}{*}{ Japan } & Roof & 753.88 & 40.48 & 75.89 & 91.07 & 5.06 & 966.38 \\
\hline & Facade & 282.71 & 5.06 & 28.46 & 45.54 & 1.90 & 362.39 \\
\hline \multirow[t]{2}{*}{ Netherlands } & Roof & 127.48 & 42.70 & 52.75 & 35.80 & 0.63 & 259.36 \\
\hline & Facade & 47.81 & 5.34 & 19.78 & 17.90 & 0.24 & 97.26 \\
\hline \multirow[t]{2}{*}{ Spain } & Roof & 251.97 & 78.74 & 55.12 & 55.12 & 7.87 & 448.82 \\
\hline & Facade & 94.49 & 9.84 & 10.67 & 27.56 & 2.95 & 168.31 \\
\hline \multirow[t]{2}{*}{ Sweden } & Roof & 134.52 & 36.11 & 32.92 & 14.51 & 0.71 & 218.77 \\
\hline & Facade & 50.45 & 4.51 & 12.35 & 7.26 & 0.27 & 82.04 \\
\hline \multirow[t]{2}{*}{ Switzerland } & Roof & 67.12 & 21.90 & 21.05 & 12.80 & 15.36 & 138.22 \\
\hline & Facade & 25.17 & 2.74 & 7.89 & 6.40 & 5.76 & 51.83 \\
\hline \multirow{2}{*}{ United Kingdom } & Roof & 601.88 & 71.09 & 61.61 & 168.24 & 11.85 & 914.67 \\
\hline & Facade & 225.70 & 8.89 & 23.10 & 84.12 & 4.44 & 343.00 \\
\hline \multirow[t]{2}{*}{ United States } & Roof & 6791.83 & 322.91 & 602.76 & 2260.36 & 118.40 & 10096.26 \\
\hline & Facade & 2546.94 & 40.36 & 226.04 & 1130.18 & 44.40 & 3786.10 \\
\hline
\end{tabular}




\section{Conclusions}

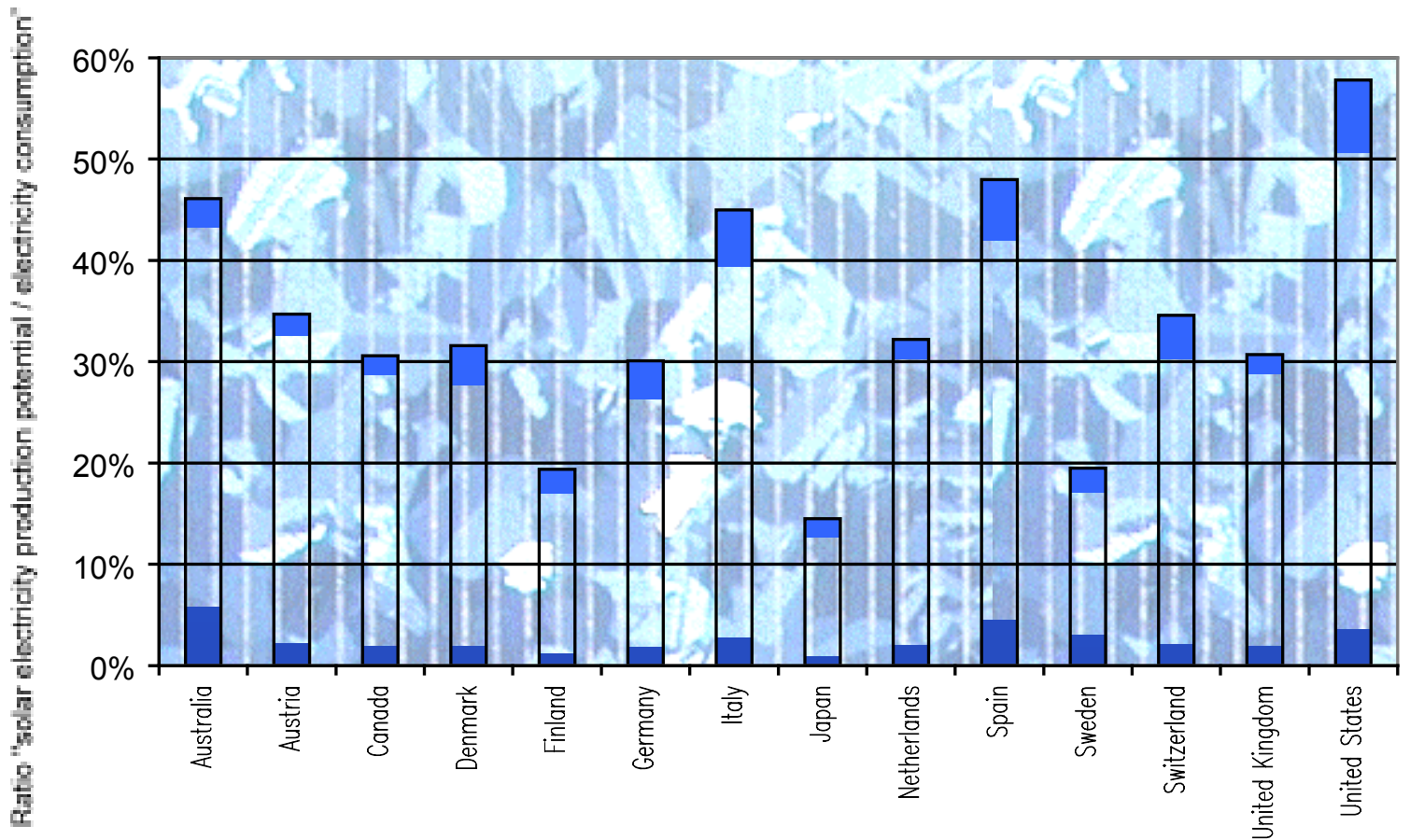

Figure 3: Achievable levels of solar power production from PV roofs and facades in IEA countries. Levels are expressed given the solar yield criterion of $80 \%$ and an overall PV system efficiency of $10 \%$ (Nowak et al. 2002).

The following general statements can be made about solar electricity production potential:

- Assuming good solar yield (about 80\%), achievable levels (ratio "BIPV solar electricity production potential/current electricity consumption") of solar power production by PV roofs and facades vary from $15 \%$ to almost $60 \%$ (Figure 3 ).

- The BIPV solar electricity production potential is even larger when a more progressive global conversion efficiency rate (more than $10 \%$ solar electricity output of total solar energy irradiated) is assumed.

- Besides technical aspects, the achievable levels depend mainly on the building areas available, on solar irradiation, and on electricity consumption.

- The achievable levels are significantly higher for the United States and Australia, and much lower for Japan. This is mainly due to available building areas. Generally, densely populated areas have less area available per capita (for example, Japan in the global IEA context, the Netherlands in the Central Western European context). The achievable levels are lower for Sweden because of the specific electricity use (high share of electricity in the energy consumption), although Sweden possesses an outstandingly high building area (for European standards). 
- Potentially $18 \mathrm{~m}^{2}$ roof area per capita are usable for PV in Central Western Europe. For the United States and Australia, this figure is approximately $36 \mathrm{~m}^{2}$, whereas in Japan only $8 \mathrm{~m}^{2}$ are available per capita.

- For facades, about $6.5 \mathrm{~m}^{2}$ of BIPV area per capita are available in Central Western Europe.

- Overall, about three-fourths of the BIPV area potential is attributed to roof areas, about one-fourth to facade areas.

- About $15 \%-20 \%$ of the BIPV electricity production potential can be attributed to facade areas.

- The relative share of area suitable for solar architecture is fairly coherent within and between the countries considered; the utilization factor (ratio between suitable area and ground floor area) is 0.4 for roofs and 0.15 for facades. These calculations enable people to easily assess the BIPV potential.

\section{Economic Considerations and Guidelines}

\section{Introduction}

Traditionally, electrical service for buildings has been provided by the utility company. Because of electricity industry restructuring and successful R\&D on BIPV, building owners must now consider whether PV for individual buildings is worth the investment. The objective of Guidelines for the Economic Evaluation of Building-Integrated Photovoltaic Power Systems is to identify the economic parameters of BIPV systems.

\section{Methodology}

The guidelines are structured in three major parts: the investment analysis (methods and ownership issues), benefits, and costs. Measurement and verification are discussed briefly.

\section{Investment Analysis}

A major barrier to analyzing renewable energy systems is assembling and presenting the technical and financial data in ways that will help an investor decide whether a BIPV system would make economic sense. Economic methods of investment analysis, such as payback period, net benefit analysis, adjusted internal rate of return (AIRR), and life cycle cost (LCC) analysis can be used to evaluate BIPV systems from the standpoint of the owner-occupant, owner-investor, and owner-developer. In each method, the discount rate plays a major role in the uncertainties of alternative costs. There are numerous good, extensive papers on this issue, so this discussion is not presented here.

Energy investment alternatives are often evaluated using payback period, net present value (NPV), savings to investment ratio (SIR), AIRR, or LCC analysis. Primary distinctions among these methodologies are the time period over which the costs and benefits are calculated, the unit of measure, and most important, their interpretation. The payback period is calculated over the minimum time it takes to recover an investment. NPV is the net of savings over costs expressed as a timeequivalent value, usually as a lump sum at the present or as a series of annual amounts. SIR is the ratio of savings to costs. AIRR is the rate assuming reinvestment of interim earnings or savings at a specified rate. LCC is the time-adjusted sum of all time-adjusted costs of a given system over the 
specified period - it must be compared to the LCC of an alternative system. The nature of the BIPV building products - to provide electricity in buildings and to act as multifunctional building components_-requires a large capital construction cost but no operating fuel costs.

BIPV systems can also accrue nonenergy economic benefits over the lifetime of the system. Commonly used evaluation methodologies for traditional buildings, which emphasize first costs or ignore nonenergy benefits of BIPV systems, may underestimate their true value and result in an unreliable or inaccurate decision. However, for the purpose of designing and sizing BIPV systems, the NPV method or the LCC method is recommended because BIPV may increase net benefits or lead to reduced (future) LCC.

Criteria for cost effectiveness can be subjective depending on the investment decision maker. Some guidelines define cost effectiveness as any energy project with an SIR greater than 1, AIRR greater than the discount rate, LCC lower than the next best alternative energy system, and simple payback period less than the life of the BIPV system.

The most likely investor/decision maker is the long-term owner-occupant, who is best positioned to reap the benefits of BIPV systems because they are capital intensive and have low operating costs.

\section{Benefits}

The benefits of BIPV cover a broad range of aspects. There are multiple (building) functions, electricity benefits, shading and thermal benefits, grid support benefits, control of load growth by utilities (institutionalized by utility and national incentives and programs), demand savings, power quality and reliability, promotional and educational benefits, environmental benefits, and security.

BIPV offers a new and attractive building material that can be used to create building designs that fit into an increasingly important architectural goal of demonstrating environmental sustainability. The most common and readily accessible site on a building for a BIPV system is often the roof. New BIPV roofing materials shaped to fit with conventional roof tiles or sheeting can save materials and installation costs without changing the appearance of the building. Similarly, transparent or semitransparent BIPV modules can readily replace standard skylights. Even standard BIPV modules installed over a roof can provide significant electricity output and a range of additional values offered by distributed generation.

Shading elements are typically secured to the outside of the building envelope to limit the amount of daylight and heat entering through a window. They are well suited to accommodate PV laminates because they are oriented toward the sun, often have a flat surface, and allow rear ventilation. They can also be automatically controlled to track the sun. Shading devices are increasingly necessary because of the trend to larger window sizes and the use of curtain walls in commercial buildings.

Passive ventilation is achieved by the "stack effect," in which warm air becomes buoyant and rises, thus creating an upward flow of air. This effect can be employed to ventilate the space adjacent to the 
column of moving warm air by extracting air through louvers or windows. This also helps to lower the BIPV operating temperature, which results in higher operating efficiencies for crystalline technologies.

Infrared radiation is largely transmitted by PV cells and contributes to heating the module and whatever is behind it. Heat generated by BIPV modules can (in certain cases) be extracted to satisfy low-grade heat demands, such as space or water heating, in a hybrid electric/thermal (PV/T) system. This combination can increase the energy efficiency and the cost effectiveness of the overall installation. However, the technology has not yet been developed.

The use of PV for soundproofing in buildings and highway barriers has been widely employed in Europe, where dense urban development makes this a premium value. A 100-kW PV sound barrier was installed in Switzerland in 1989. A variety of designs have since been developed and installed in Switzerland and Germany, some as a result of an international design competition. Innovative designs are now using bi-facial PV cells, which allow the use of light from north- and south-facing surfaces, thus increasing the annual electricity output.

PV has the following advantages:

- Modularity

- Fuel diversity

- Reduced price volatility

- Local and community choice and control

- Avoided emissions and other environmental impacts.

For PV, the lower energy density of the solar resource results in suitable sizes; economies of scale are achieved by increases in production volumes rather than installation size.

Compared to central PV stations, decentralized systems smooth output fluctuations and provide a better match to loads, thus providing a higher capacity value from the utility point of view. This has been verified by studies undertaken in Japan, which show that regional output becomes more important for decentralized systems than the output from individual systems.

Distributed generation can reduce costs for infrastructure such as line capacity and peak load generation facilities, as well as for network operation and maintenance (O\&M) costs. It can also delay or eliminate the need for network augmentation. Generation close to the load user also reduces network losses, which can be as high as $25 \%$ of the electricity distributed through rural lines.

The decentralized use of PV is an important tool to cope with the current environmental problems associated with electricity generation and use. The core idea is that decentralized PV applications could affect supply- and demand-side issues. More precisely, a major driver for increases in energy demand and corresponding carbon dioxide emissions are consumers' behaviors, lifestyles, and longterm investment decisions. Therefore, besides substituting for air-polluting fossil-fuel power plants, PV could also serve as a vehicle for triggering energy conservation by influencing consumers' 
awareness of electricity consumption. Moreover, PV may also contribute to a utility company's objective of load management by means of "peak load shaving."

Table 3: Summary of Values That Can Be Attributed to PV Systems (Eiffert 2002)

\begin{tabular}{|c|c|}
\hline Category & Potential Values \\
\hline Electrical & $\begin{array}{l}\text { KWh generated; kW capacity value; peak generation and load matching value; } \\
\text { reduction in demand for utility electricity; power in times of emergency; grid support } \\
\text { for rural lines; reduced transmission and distribution losses; improved grid reliability } \\
\text { and resilience; voltage control; smoothing load fluctuations; filtering harmonics and } \\
\text { reactive power compensation }\end{array}$ \\
\hline Environmental & $\begin{array}{l}\text { Significant net energy generator over its lifetime; reduced air emissions of } \\
\text { particulates, heavy metals, } \mathrm{CO}_{2}, \mathrm{NO}_{\mathrm{x}}, \mathrm{SO}_{\mathrm{x}}-- \text { resulting in lower levels of } \\
\text { greenhouse gases, reduced acid rain, and lower smog levels; reduced power } \\
\text { station land and water use; reduced impact of urban development; reduced tree } \\
\text { clearing for fuel; reduced nuclear safety risks }\end{array}$ \\
\hline Archite & $\begin{array}{l}\text { Substitute building component; multi-function potential for insulation, water } \\
\text { proofing, fire protection, wind protection, acoustic control, daylighting, shading, } \\
\text { thermal collection, and dissipation; aesthetic appeal through color, transparency, } \\
\text { non-reflective surfaces; reduced embodied energy of the building; reflection of } \\
\text { electromagnetic waves; reduced building maintenance and roof replacements }\end{array}$ \\
\hline $\begin{array}{l}\text { Socio- } \\
\text { Economic }\end{array}$ & $\begin{array}{l}\text { New industries, products, and markets; local employment for installation and } \\
\text { servicing; local choice, resource use, and control; potential for solar breeders; short } \\
\text { construction lead times; modularity improves demand matching; resource } \\
\text { diversification; reduced fuel imports; reduced price volatility; deferment of large } \\
\text { capital outlays for central generating plant or transmission and distribution line } \\
\text { upgrades; urban renewal; rural development; lower externalities (environmental } \\
\text { impact, social dislocation, infrastructure requirements) than fossil fuels and } \\
\text { nuclear; reduced fuel transport costs and pollution from fossil fuel use in rural } \\
\text { areas; reduced risk of nuclear accidents; symbol for sustainable development and } \\
\text { associated education; potential for international cooperation, collaboration, and } \\
\text { long-term aid to developing countries }\end{array}$ \\
\hline
\end{tabular}

\section{Beneficiaries}

Beneficiaries include utilities; building owners and occupants; the design, engineering, and construction industry; and society as a whole. The benefits offered by PV to utilities, architects, and developers also extend to customers. Improved thermal comfort and soundproofing, reduced energy demand charges, and interesting building design features are important to customers. In addition, customer surveys around the world increasingly show an interest in the impacts of energy systems on the environment and quality of life. Customers are also interested in increasing their levels of energy self-reliance and portraying a clean image. The perceived benefits of PV depend to some extent on the perspective from which it is viewed. For instance:

- The building owner may be interested in offsetting building costs, enhancing property value, and improving rental prospects.

- The building tenant may attribute value to visual appeal and green image, as well as reduced power bills, increased self-reliance, and high-quality, reliable electricity. 
- The value to the community may be visual amenity, enhanced property values, local employment, reduced power outages or brownouts, safety, and reduced local and global pollution levels.

- The value to the nation may be determined by creating employment, reducing pollution, increasing energy self-reliance, and decreasing dependence on fossil fuels [Watt et al. 1999].

\section{Costs}

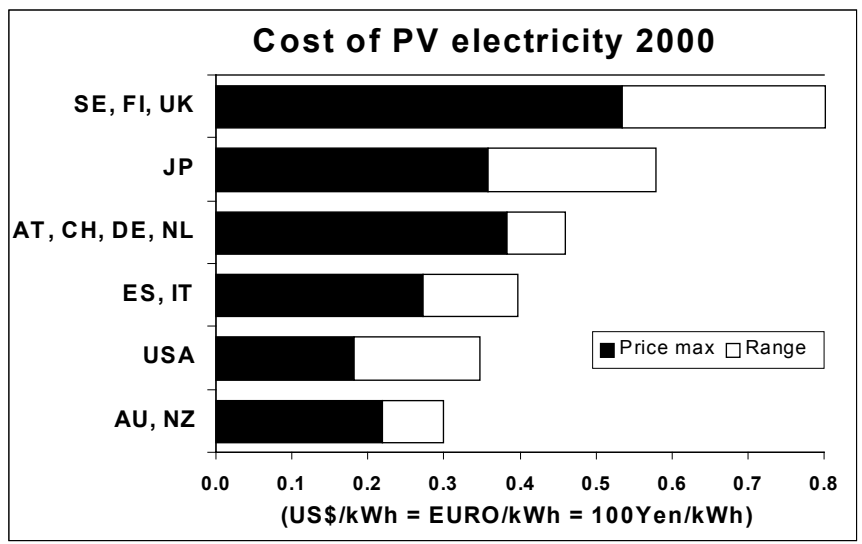

Figure 4: Range of costs per kWh of PV electricity in selected OECD countries in 2000, related to small systems of $3 \mathrm{~kW}_{\mathrm{p}}$ (Haas 2002).

The costs of PV vary tremendously among countries. Most interesting is a comparison with household electricity prices. Figure 5 depicts the range of household electricity prices in selected OECD countries in 2000. Figure 6 shows that in the best areas of Australia and the United States, the generation costs are closer to the household electricity prices. In Central and Northern Europe, the prices are still around half a Euro or US\$, which is not cost effective. Look at the ratio R of costs per kilowatt-hour of PV electricity divided by electricity prices ( $\mathrm{R}=1$ means cost-effectiveness). Figure 6 shows that in parts of the United States, Japan, and Australia, it is at least smaller than 2; in Northern Europe, it is still higher than 4.

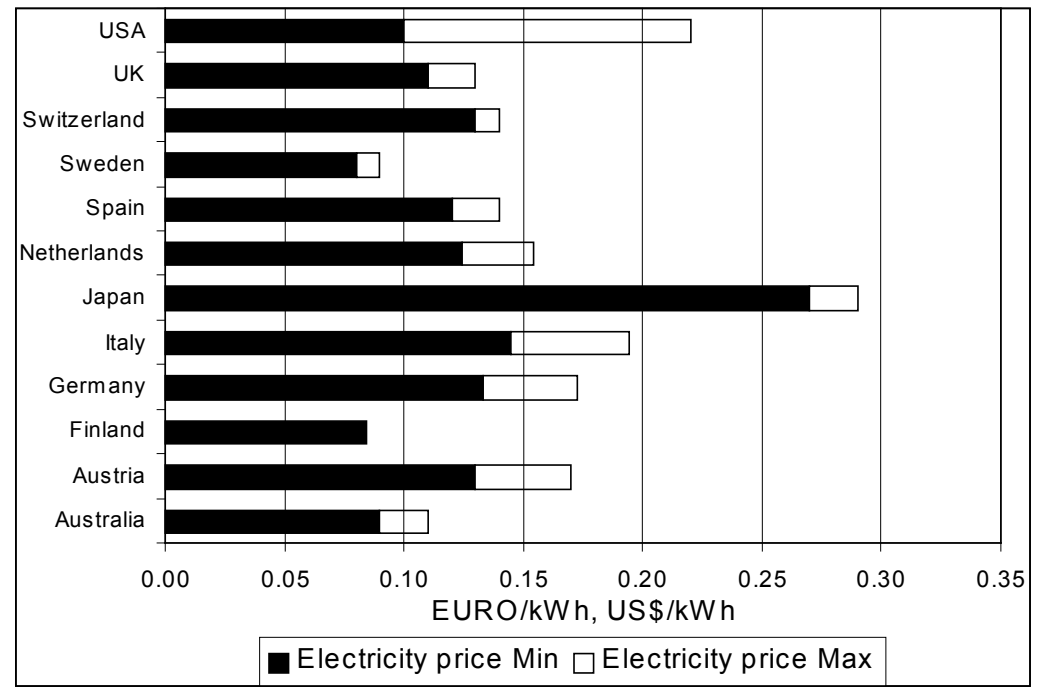

Figure 5: Range of household electricity prices in selected OECD countries in 2000 (Haas 2002). 


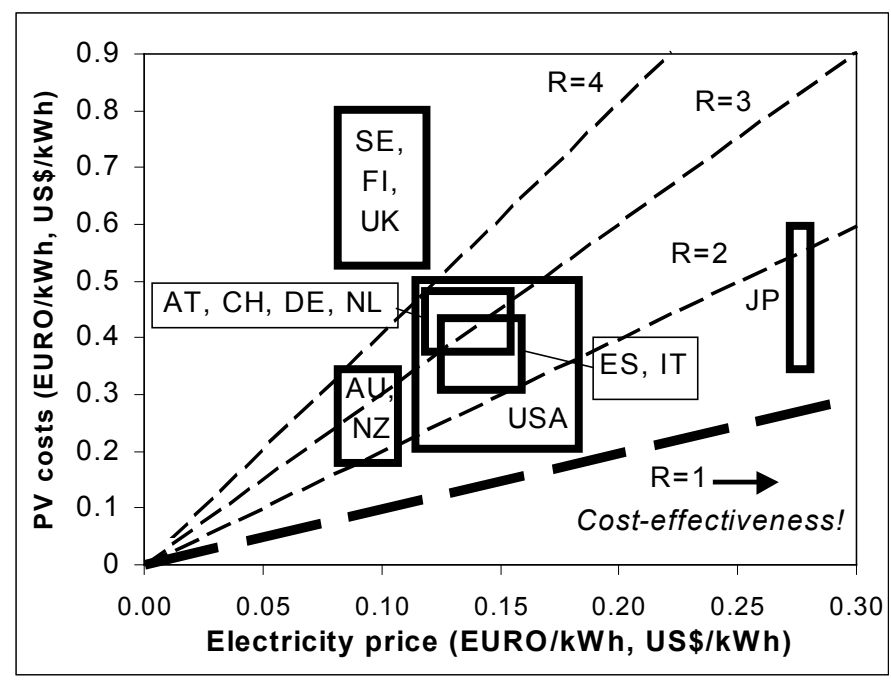

Figure 6: Range of electricity prices and costs per kWh PV electricity in selected OECD countries in 2000; $R=$ ratio of PV generation costs/electricity price (Haas 2002).

The costs of BIPV depend on the system technology, utility interconnection costs, labor and installation costs, associated costs for building permits, maintenance costs, costs for replacement and repair, and the salvage costs (or value).

BIPV systems are composed of PV modules and balance of system (BOS) components, which include inverters, an electricity storage system or grid-metered connection, fault protection, cabling, and wiring. These costs, as well as those of integration design and installation, should be evaluated in comparison to the traditional construction products and systems to determine the marginal cost of the BIPV system. The cost of a BIPV system should also be compared to using a stand-off system added to an established building.

Architects are beginning to explore the design possibilities of PV, integrating it into their buildings as daylighting, shading, and facade features. Aspects of BIPV elements important to these functions include the color, shape, and transparency of the BIPV module. Custom designs will result in more expensive BIPV modules, while in general, product standardization is necessary for cost reduction.

Until BIPV becomes a mainstream technology, there is a marginal added labor cost of specialized architectural design, engineering design, and installation. However, with technical supervision, traditional building tradesmen such as glaziers, roofers, sheet metal workers, and electricians can install BIPV systems.

Building permits are usually required before any building is constructed, added to, moved, or altered. Electrical permits are required for new, remodeled, or upgraded structures. Some costs include fees for land disturbance, residential or commercial building permit fees, and reinspection fees. Building permit fees vary from county to county, state to state, and country to country, and are based on the estimated cost of construction or building floor area. Therefore, permit fees may be increased by adding a BIPV system. Contact local land use and building officials to identify permit requirements. 
Manufacturers recommend periodic system checks and cleaning as part of a preventive maintenance routine. This includes regularly clearing away debris and cleaning the PV surfaces exposed to the environment. Rain or water from a garden hose often is sufficient to keep the system clean. As a rule, visual inspection of essential components, based on an inspection checklist provided by the manufacturer or the installer, should be made every six months. The utility meter and bill can be reviewed monthly to determine whether output from the system is dropping (adjusting for seasonal or other mitigating factors). Further investigation is warranted if this simple screening indicates poor system performance.

Utility interconnection costs are associated with the specific requirements determined by each local authority. Public utility companies have widely varying requirements and attitudes. Costs can include interconnection fees, net metering tariffs, metering calibration charges, engineering study fees, and standby charges. Additional requirements for liability insurance, property easement, legal indemnification, record keeping of all operation and maintenance (O\&M) costs, and additional protection equipment will contribute to utility interconnection costs. The relative cost of meeting these requirements can be much higher for small systems than for larger systems.

\section{Market Strategies}

\section{Introduction}

In the last decade of the 20th century, the worldwide market penetration of PV increased tremendously (Figure 7). In 1990, standalone systems in remote areas and the applications for communication and consumer products were prevailing; at the end of the decade, small, decentralized grid-connected systems became dominant. A wide variety of promotional strategies and dissemination programs led to this development, and different organizations and institutions launched these initiatives.

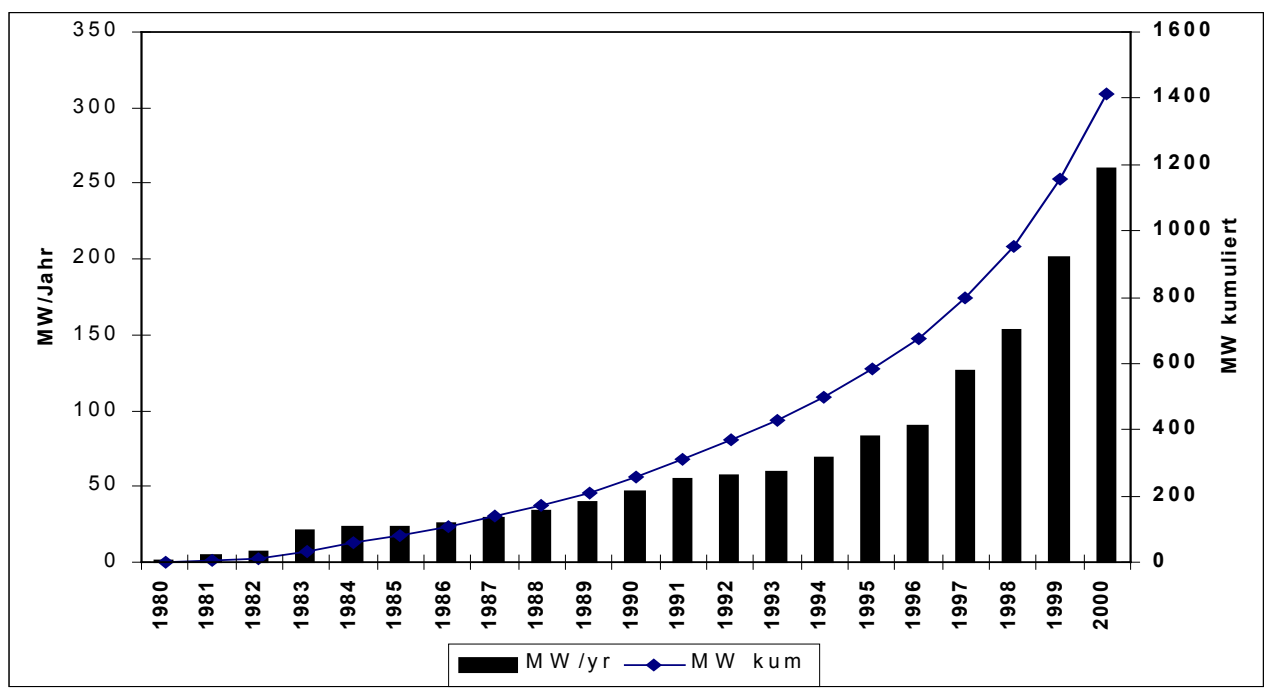

Figure 7: The development of the world PV market 1980-2000 (Haas 2002). 
The core objective of this research is to determine the criteria for successful market deployment strategies for the broader dissemination of grid-connected PV systems in the built environment. Ultimately, the research must identify relevant criteria for successful dissemination strategies and derive recommendations for further actions with respect to target groups.

\section{Methodology}

Of course, programs and projects that can provide some lessons learned are most interesting. Hence, in this report, major emphasis is placed on programs from which experience is already available, and minor focus is placed on programs that have been recently announced. The criteria for successful marketing strategies for PV from society's point of view are derived by the method displayed in Figure 8. First, it is necessary to qualitatively identify the benefits, or added values, of PV (for example, environmental benignity, load-shaving, modularity). Next it is relevant to investigate the quantitative potential the technology can contribute to solving a problem and/or to meet a certain societal objective, such as providing energy services for private households. After estimating the potential benefits, it is necessary to identify the relevant areas of activities (the customer, the market, the technology) to identify barriers and to be addressed by a strategy in which action must be taken. Furthermore, in each area of activity the major barriers (lack of technical reliability, high investment costs, no social acceptance) that impede a broader market penetration have to be investigated. Then the target groups are defined (private individuals, PV industry, architects, governments) for actions to be taken. Following this, possible strategies (financial incentives, information campaigns, and education campaigns) can be derived and assessed to overcome the barriers. Of course, some iteration is necessary. After identifying areas of activity and the corresponding barriers, it may be necessary to revisit and reaffirm added values as well as potentials.

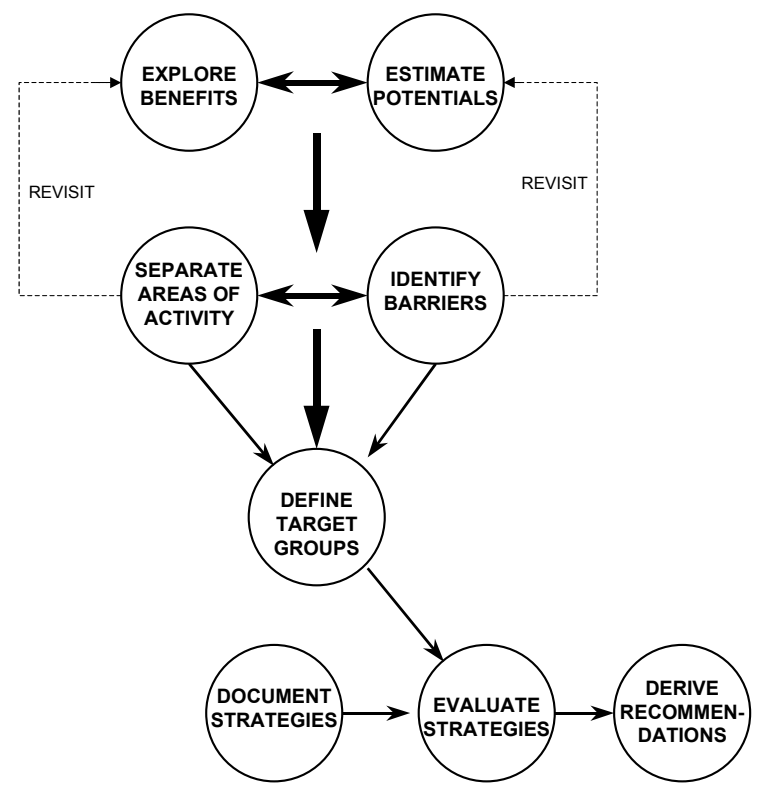

Figure 8: Steps for deriving a marketing strategy for a technology (Haas 2002). 


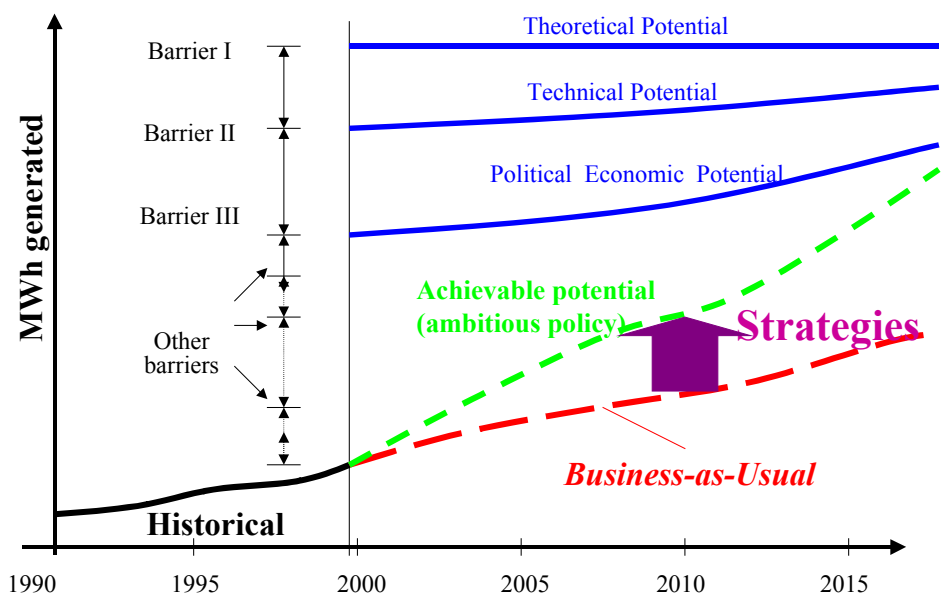

Figure 9: The generated electricity versus time. Its historical context of the interaction among potentials, barriers, and strategies (Haas 2002).

Figure 9 depicts how potentials, barriers, and strategies are linked in principle. The electricity generated is shown depending on the time. The historical development of PV in a certain country is shown, as well as the different potentials. Various barriers impede the practical achievement of the potentials. If no policy strategies are implemented, the lower broken line will be achieved, the socalled business-as-usual scenario. If an ambitious policy launches the proper strategies, the upper broken line will be achieved.

In recent years, a wide variety of dissemination strategies have been implemented in various OECD countries; the major features/dimensions of dissemination strategies are described. Next, a survey on which types of promotion strategies exist in principle and how they work is provided. How these strategies are implemented in real life by means of specific programs in certain areas or countries is depicted.

\section{Results}

PV customers are the crucial target group of a market deployment strategy, next to society, technology, and PV suppliers. Most important for the successful marketing of any product is knowing the interests, needs, and wishes of potential customers, the different types of customers, and the factors influencing the customers decision-making process to buy a product. The consumers' WTP depends on income/ affordability, investment costs, information, environmental benignity, reliability, technical efficiency, autonomous electricity supply, and acceptance.

It is of interest to know how these parameters, combined in the WTP, is interpreted by a demand curve. The basic principle (with random numbers) is depicted in Figure 10, showing in principle how customers' WTP depends on various impact categories. This concept may be helpful for deriving an appraisal of the future strategies and potentials. 


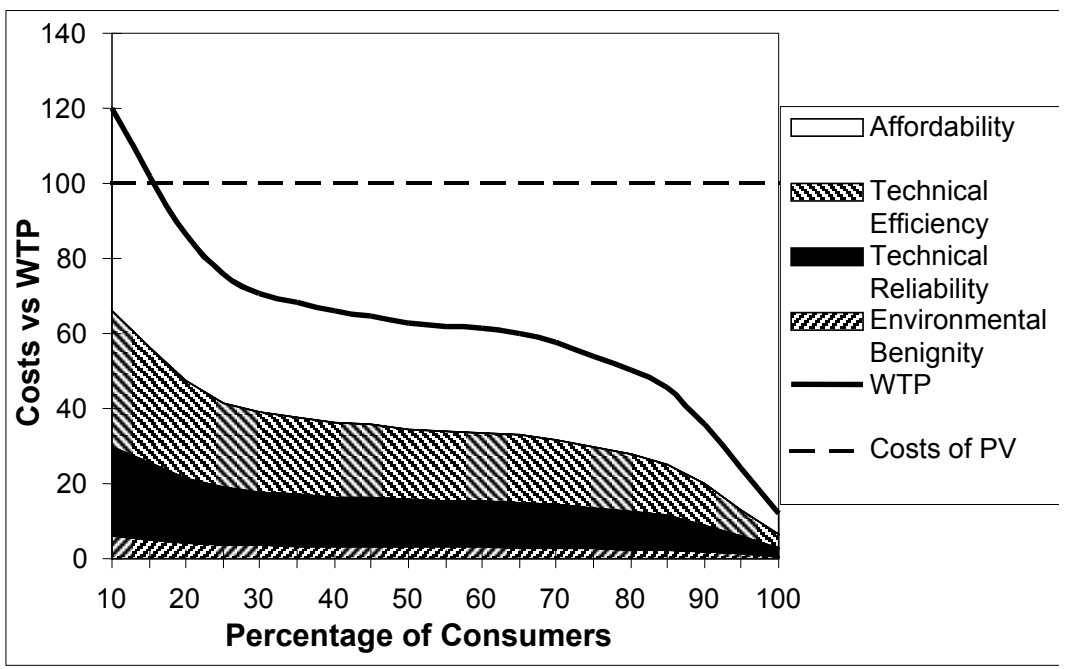

Figure 10: WTP for PV systems depending on various features (Haas 2002).

The major objectives are:

- Remove the barriers for a broader market penetration

- Increase the installed capacity and the market penetration of PV

- Enjoy the corresponding environmental benefits.

Related targets are:

- Exhaust customers' WTP

- Increase social acceptance and public awareness

- Reduce costs per kilowatt-hour generated

- Improve technical reliability, technical performance, and standardization

- Remove obstacles to grid connection

- Minimize costs to the public: strive for low administration and transaction costs, and minimize public financial support to reach a certain amount of installed PV capacity

- Lead to sustainable growth of the PV industry.

There are six possible features of successful dissemination strategies for decentralized PV systems (Figure 11). 


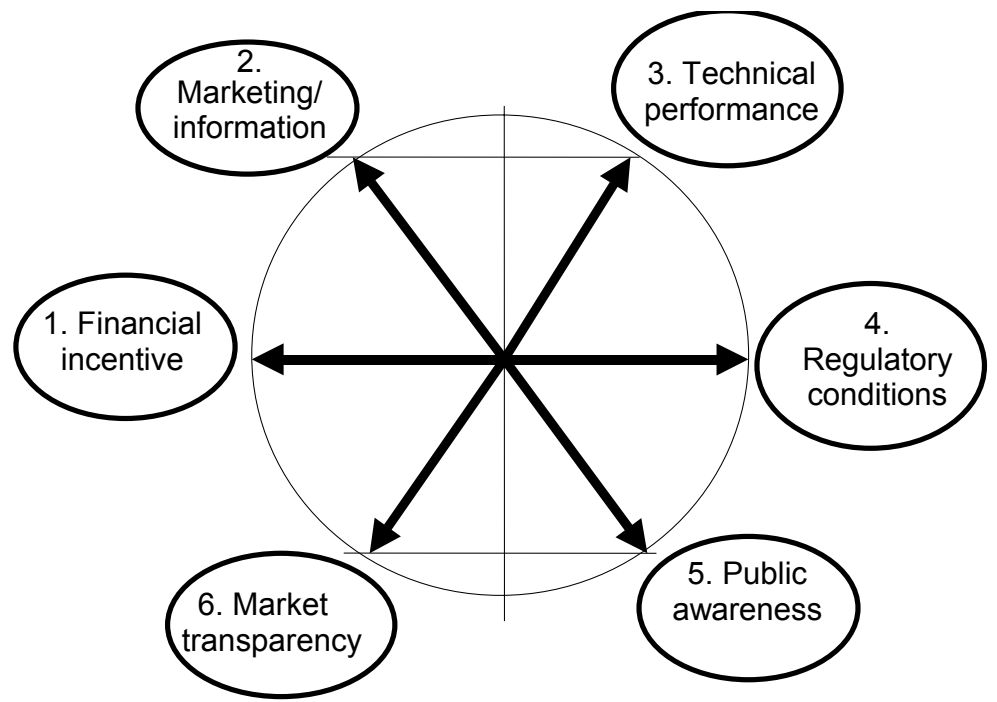

Figure 11: Features/components of dissemination strategies (Haas 2002).

1. A financial incentive (either regulated or voluntary) may be important to improve the economic performance of PV systems. Moreover, there are three main financial incentives: (i) be a subsidy on the capacity or the electricity generated; (ii) be an attractive financing offer; (iii) offer a standardized system at a low price ("discount").

2. A successful strategy must identify the potential participants of a program and their needs. Moreover, it has to provide detailed and targeted technical and practical information on how and where to install the PV system, its cost, and components.

3. The technical reliability, conversion efficiency, and simplicity of installing the system are important criteria for customers. This should be addressed in a strategy by means of guaranteed yields, labeled products, and technical monitoring. Moreover, technical performance can also be improved in a strategy promoting and financing standards development and technology R\&D.

4. Especially in deregulated markets, it is important that distortions caused by environmental effects, or not including external costs, are corrected by the governments. This can be done by regulatory rates, national quotas, or governmental rebates.

5. Next, the social component must be addressed. Public acceptance for PV is in general no problem, but the state of knowledge and public awareness is. Public awareness can be improved by launching general information on environmental problems and values added by PV, such as local job creation. Moreover, it is often important to make the program a social event. Addressing the mass media in a proper way is tremendously important.

6. Finally, an important feature of a strategy may be to enhance the transparency of the market. This applies to the PV system market as well as the general market for electricity. With respect to the market for PV systems, a market and product survey may be conducted. This may help to substantially reduce transaction costs for the customer. Regarding the electricity market, it may be important to enhance transparency on current fuel mix of electricity supply by means of an energy source label.

The matrix in Table 4 provides a survey of which features/components of strategies to remove specific types of barriers are listed, as well as the target groups addressed. Costs and the bad economic 
performance are important barriers for widespread use of PV. Financial incentives are undoubtedly the most important single feature of dissemination strategies for PV. With respect to financial incentives as a promotion strategy for a technology, the dynamics of the investment costs and the WTP of private or commercial investors must be taken into account.

Table 4: Barriers, Features of Strategies, and Target Groups to Be Addressed (Haas 2002)

\begin{tabular}{|c|c|c|c|c|c|c|}
\hline $\begin{array}{l}\text { FEATURE OF } \\
\text { STRATEGY } \\
\text { TARGET } \\
\text { GROUP } \\
\text { |BARRIER }\end{array}$ & 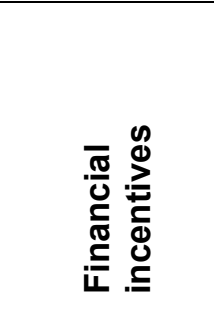 & 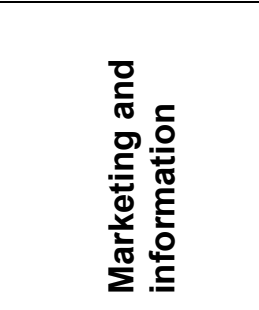 & 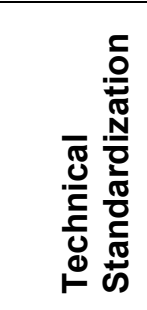 & 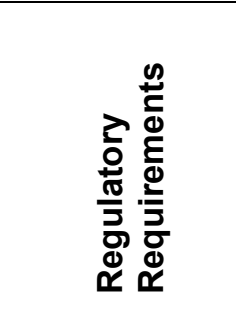 & 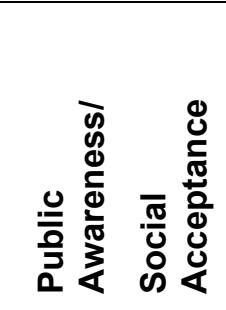 & 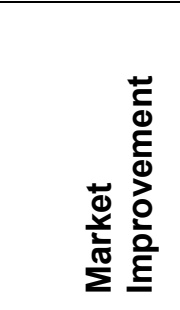 \\
\hline $\begin{array}{l}\text { A. Bad economic } \\
\text { performance }\end{array}$ & $\begin{array}{l}\text { private } \\
\text { customers }\end{array}$ & & $\begin{array}{l}\text { PV } \\
\text { industry }\end{array}$ & $\begin{array}{l}\text { national and } \\
\text { local } \\
\text { governments }\end{array}$ & & PV industry \\
\hline $\begin{array}{l}\text { B. High transaction } \\
\text { costs for customers }\end{array}$ & & $\begin{array}{l}\text { local } \\
\text { government and } \\
\text { utilities }\end{array}$ & $\begin{array}{l}\text { PV } \\
\text { industry }\end{array}$ & government & $\begin{array}{l}\text { local } \\
\text { government, } \\
\text { electrical and } \\
\text { building } \\
\text { industries }\end{array}$ & $\begin{array}{l}\text { private } \\
\text { customers }\end{array}$ \\
\hline C. Low private WTP & $\begin{array}{l}\text { financing } \\
\text { sector }\end{array}$ & $\begin{array}{l}\text { private } \\
\text { customers }\end{array}$ & & & $\begin{array}{l}\text { community, } \\
\text { private } \\
\text { customers }\end{array}$ & $\begin{array}{l}\text { community, } \\
\text { private } \\
\text { customers }\end{array}$ \\
\hline $\begin{array}{l}\text { D. Lack of } \\
\text { architectural } \\
\text { acceptance } \\
\end{array}$ & & architects & $\begin{array}{l}\text { PV } \\
\text { industry }\end{array}$ & $\begin{array}{l}\text { building } \\
\text { industry, local } \\
\text { government }\end{array}$ & PV industry & PV industry \\
\hline $\begin{array}{l}\text { E. Lack of financing } \\
\text { strategies }\end{array}$ & $\begin{array}{l}\text { finance } \\
\text { sector }\end{array}$ & finance sector & & & & PV industry \\
\hline $\begin{array}{l}\text { F. Imperfect non- } \\
\text { transparent } \\
\text { markets, low } \\
\text { competition }\end{array}$ & government & $\begin{array}{l}\text { private } \\
\text { customers }\end{array}$ & & $\begin{array}{l}\text { PV industry, } \\
\text { electricity } \\
\text { industry, } \\
\text { government }\end{array}$ & $\begin{array}{l}\text { community } \\
\text { government }\end{array}$ & $\begin{array}{l}\text { government } \\
\text { utilities }\end{array}$ \\
\hline $\begin{array}{l}\text { G. Lack of technical } \\
\text { reliability }\end{array}$ & $\begin{array}{l}\text { PV industry, } \\
\text { government, } \\
\text { PV } \\
\text { customers }\end{array}$ & & $\begin{array}{l}\text { PV } \\
\text { industry, } \\
\text { R\&D }\end{array}$ & PV industry & & $\begin{array}{l}\text { PV industry, } \\
\text { government }\end{array}$ \\
\hline $\begin{array}{l}\text { H. Lack of system } \\
\text { standardization }\end{array}$ & $\begin{array}{l}\text { government, } \\
\text { PV industry, } \\
\text { building } \\
\text { industry }\end{array}$ & & $\begin{array}{l}\text { PV } \\
\text { industry, } \\
\text { R\&D }\end{array}$ & $\begin{array}{l}\text { national and } \\
\text { local } \\
\text { governments }\end{array}$ & & $\begin{array}{l}\text { PV industry, } \\
\text { building } \\
\text { industry }\end{array}$ \\
\hline $\begin{array}{l}\text { I. Environmental } \\
\text { benefits not } \\
\text { rewarded }\end{array}$ & & $\begin{array}{l}\text { private } \\
\text { customers }\end{array}$ & & $\begin{array}{l}\text { government } \\
\text { utilities }\end{array}$ & $\begin{array}{l}\text { national and } \\
\text { local } \\
\text { governments }\end{array}$ & $\begin{array}{l}\text { electricity } \\
\text { industry }\end{array}$ \\
\hline $\begin{array}{l}\text { J. Low public } \\
\text { awareness }\end{array}$ & & $\begin{array}{l}\text { private } \\
\text { customers, local } \\
\text { government }\end{array}$ & & & PV industry & PV industry \\
\hline
\end{tabular}


Most important is how the dynamics of investment costs and the WTP influence the magnitude of optimal dynamic incentives. Figure 12 shows how market equilibria with and without subsidies may look for a certain point of time.
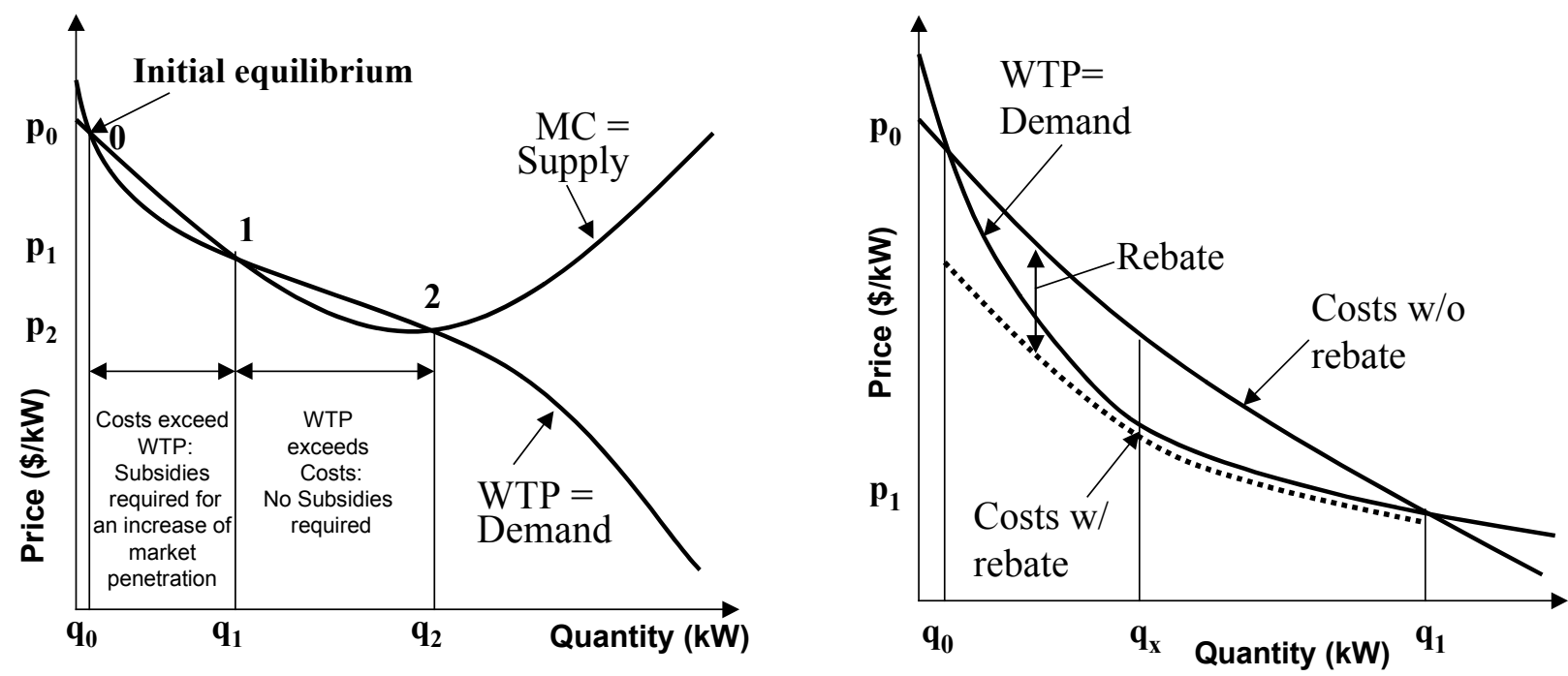

Figure 12 (left): Price versus customers' WTP and the relevance of subsidies (Haas 2002).

Figure 13 (right): Rebates required to increase market penetration (Haas 2002).

Figure 12 shows a possible long-term equilibrium without subsidies in which a far higher quantity of the technology is installed than at the current equilibrium. Yet to reach this equilibrium, rebates are required to move from $\mathrm{q} 0$ to $\mathrm{q} 1$. This item is depicted in detail in Figure 13. The maximum rebate is given from the difference between supply and demand curve at qx. Of course an increase of subsidies to enhance the quantity sold is not possible because nobody would purchase a system if he knows that he gets more subsidies next year. Furthermore, it can be argued that subsidies are justified as long as they reflect the societal benefit.

\section{Evaluation of National Programs}

Table 5 provides an overview on the major strategies currently implemented in various OECD countries and on additional instruments applied. Table 5 reflects that enhanced feed-in tariffs are currently the most popular dissemination strategy, followed by rebates and green tariffs. The core question is: Which program types were successful, and which strategies are most promising? Of special interest is the difference between regulatory and voluntary strategies and strategies focusing on investments and strategies focusing on payments per kWh ("regulated rates").

Both voluntary national target programs launched so far (in the Netherlands and Switzerland) without substantial financial incentives have been successful. The Dutch program surpassed its first goal of 7.7 MW in 2000. In Switzerland, about $15 \mathrm{MW}$ of the goal of $50 \mathrm{MW}$ was attained by the end of 2000. National target programs ("covenants") work if they are pursued seriously, accompanied by 
information and education activities, and if there are clearly defined and achievable annual targets. Moreover, carefully conducted progress reports must be provided. With respect to mandatory target programs for PV so far, their success cannot be evaluated because not enough experience is available.

Table 5: Prevailing Dissemination Strategies for PV Electricity in Selected OECD Countries (Haas 2002)

\begin{tabular}{|c|c|c|}
\hline Country & Current Major Strategy & Additional Programs \\
\hline Australia & rebates & green tariffs, green electricity targets \\
\hline Austria & rebates and feed-in tariffs & RPS (4\% "new" renewables by 2007) \\
\hline Belgium & no & \\
\hline Denmark & no & \\
\hline Finland & no & \\
\hline France & $\begin{array}{l}\text { grants for PV, rural areas (standalone } \\
\text { systems) }\end{array}$ & \\
\hline Germany & regulated rates & $\begin{array}{l}\text { soft loans, green power marketing, } \\
\text { public building programs }\end{array}$ \\
\hline Italy & no & regulated rates \\
\hline Japan & rebates & green pricing (intended) \\
\hline The Netherlands & national target program for $\mathrm{PV}$ & green tariff, financing \\
\hline Norway & no & \\
\hline Portugal & regulated rates & \\
\hline Spain & regulated rates (royal decree) & funds (P.A.E.E.) \\
\hline Sweden & rebates and tax reliefs & regulated rates for small generators \\
\hline Switzerland & $\begin{array}{l}\text { solar stock exchange, "Solarstrom vom } \\
\text { E-Werk" }\end{array}$ & green tariffs \\
\hline UK & no & school program \\
\hline USA & rebates $(\mathrm{CA})$ & $\begin{array}{l}\text { RPS, net metering, green pricing, green } \\
\text { power marketing }\end{array}$ \\
\hline
\end{tabular}

Rebates are generally effective in enhancing PV's market penetration in a nascent market. Moreover, they ensure a maximum use of decentralized PV electricity. Investigations about the effects of rebate programs in various countries are still ongoing.

Financing/soft loans work similarly to rebates. The available experience is rather limited. The lessons learned so far from Germany's 100,000 Roofs Program are ambiguous.

Tax incentives in both forms-deduction of income tax and relief from tax based on electricity generation-may support and complete rebates and soft loans. But they have not so far substantially increased the market penetration of PV.

Of the three types of regulated rates applied in various countries in recent years, rate-based incentives (enhanced feed-in tariffs) most successfully increased market penetration. Virtually all programs based on regulated rates close to the production costs and guaranteed over a period of about 15 years were successful.

The most promising strategy under the voluntary capacity-based programs is green shareholder programs. These are usually very successful as a first step of market introduction in a local area. The 
programs implemented so far have been especially successful if they were accompanied by social events such as shareholder meetings, solar parties, and follow-up activities like striving for installations on all local public buildings.

Green tariffs and solar stock exchanges are based on a consumers' high WTP for "green electricity" and trust in the seriousness of the "old" incumbent utility. Hence, they strongly depend on the credibility of the organization that offers it. Most important, they are accompanied by a credible green label. Moreover, if all electricity displayed labels, the attractiveness of green pricing programs might be even higher.

Green power marketing is a new strategy in a liberalized, deregulated market. Experience so far shows that, as with green pricing for PV, it is only promising if it is accompanied by an attractive and credible green label. This means the label must guarantee a certain amount of PV from new installations. Furthermore, a major precondition for the success of green power marketing is that all barriers for potential green electricity users should be removed. There should be no fees for changing the supplier and no additional metering charges.

Recently launched voluntary nongovernment organization (NGO) initiatives have been surprisingly successful. They proved that customers have a high WTP if a strategy is launched by an environmentally credible organization.

\section{Conclusions}

The most important results and conclusions of this analysis are:

- Affordability, rather than pure cost effectiveness, is crucial for private customers.

- Comprehensive information and education activities must accompany financial incentives.

- High environmental credibility of the institution or company that launches a voluntary strategy based on customers' WTP (green pricing or a solar stock exchange) is an important precondition.

- Financial incentives must show a decreasing characteristic over time and be designed dynamically.

- Promotion programs should take into account consumers' WTP. Optimal financial incentives would provide only the difference between the system costs and the WTP for PV. Consumers' WTP for PV appears to be higher than expected.

- Predictability and continuity are important.

Finally, eight key factors for successful dissemination strategies of small, grid-connected PV systems have been identified:

1) Provide a minimum financial incentive that will fully exhaust customers' WTP.

2) Improve the market. Ensure that the competitiveness and transparency of the PV system market and of the electricity market are enhanced. Ensure continuity of the strategy and sustainable growth of the industry.

3) Strive for a guaranteed technical performance and an increase of standardization and efficiency.

4) Make the program a social event that addresses the public and the mass media. 
5) Strive to set the correct regulatory conditions from society's point of view. Remove barriers for access to the grid, and introduce environmental pricing.

6) Minimize costs to the public. Strive for low administration and transaction costs and minimize monetary financial support to reach a certain amount of PV capacity.

7) Provide comprehensive detailed and targeted information for potential program participants.

8) Conduct marketing. Identify the potential customers and their needs.

Successful market penetration requires strategies in which governments, the PV industry, utilities, NGOs, and potential investors cooperate closely.

\section{Summary}

The technical innovation of BIPV requires the necessary institutional support to realize its promise of being a viable technology and a sustainable solution. Part of the objective of Task 7 is to assess and remove the non-technical barriers for BIPV's introduction as an energy-significant option. To meet this objective, Task 7 emphasizes:

- An assessment of barriers in the marketplace

- The potential for PV in the built environment

- The determination of the value and economic considerations and guidelines

- An overview of current international market strategies.

Financing, administration, architectural communications, marketing, and environmental factors create barriers that slow the deployment of the BIPV technology. These barriers have been identified and categorized according to the parties involved.

The widely recognized potential for BIPV as a significant energy supplier is quantified at $15 \%$ to almost $60 \%$ of the available PV roofs and facades, assuming a good solar yield of about $80 \%$ achievable levels (ratio "BIPV solar electricity production potential/current electricity consumption"). These achievable levels are significantly higher for the United States and Australia $\left(36 \mathrm{~m}^{2}\right)$ and much lower for Japan $\left(8 \mathrm{~m}^{2}\right)$. This is mainly due to available building areas. Central Western Europe has 18 $\mathrm{m}^{2}$ potential PV roof area per capita.

Economic parameters are structured in three major guideline parts: investment analysis, benefits, and costs. PV costs vary tremendously over time from region to region. In parts of the United States, Japan, and Australia, the ratio (costs per kilowatt-hour of PV electricity divided by electricity prices of households) is smaller than 2 (close cost effectiveness); in Northern Europe it is still more than 4. (Ratio of 1 is cost effective.) Nonetheless, the evaluation of national strategies indicates that affordability, rather than pure cost effectiveness, is crucial for private customers. Promotion programs should take into account that consumers' WTP depends more on variables than on costs. 
To successfully disseminate strategies for small grid-connected PV systems, eight valuable preconditions are identified: financial incentives, marketing/information, technical performances, regulatory conditions, public awareness, market transparency, market improvement, and minimized (administrative) costs. 


\section{REPORT DOCUMENTATION PAGE}

Form Approved

OMB NO. 0704-0188

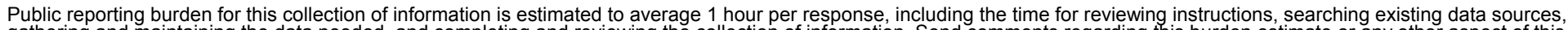

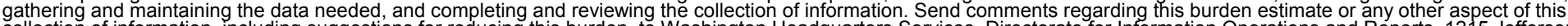

to Washington Headquarters Services, Directorate for Information Operation

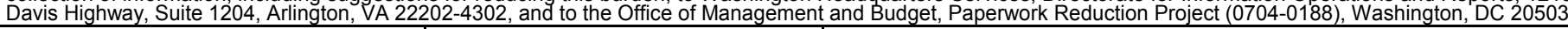
1. AGENCY USE ONLY (Leave blank)
2. REPORT DATE
January 2003
3. REPORT TYPE AND DATES COVERED
Technical Report

4. TITLE AND SUBTITLE

Non-Technical Barriers to the Commercialization of PV Power Systems in the Built

Environment

6. $\operatorname{AUTHOR}(\mathrm{S})$

P. Eiffert and the International Energy Agency (IEA) PVPS Task 7

7. PERFORMING ORGANIZATION NAME(S) AND ADDRESS(ES)

National Renewable Energy Laboratory

1617 Cole Blvd.

Golden, CO 80401-3393

9. SPONSORING/MONITORING AGENCY NAME(S) AND ADDRESS(ES)

8. PERFORMING ORGANIZATION REPORT NUMBER

NREL/TP-550-31976

10. SPONSORING/MONITORING AGENCY REPORT NUMBER

11. SUPPLEMENTARY NOTES

12a. DISTRIBUTION/AVAILABILITY STATEMENT

National Technical Information Service

12b. DISTRIBUTION CODE

U.S. Department of Commerce

5285 Port Royal Road

Springfield, VA 22161

13. ABSTRACT (Maximum 200 words)

Building-integrated photovoltaics (BIPV) requires institutional support to become a viable technology and a sustainable solution. Between 1990 and 2000, the solar industry demonstrated the viability of BIPV technology by installing hundreds of thousands of successful systems around the world. Architects have created award-winning, elegant solar buildings. Utility companies and municipalities have adopted this technology to augment their infrastructure and electricity services network. The potential for BIPV is widely recognized as significant; however, institutional barriers can slow its deployment.

Our research emphasizes institutional issues related to introducing and commercializing photovoltaic (PV) power systems in the built environment. This overview includes an assessment of barriers in the marketplace, the potential for PV in the built environment, the determination of the value and economic considerations and guidelines, and an overview of current international market strategies.

14. SUBJECT TERMS

photovoltaics; building-integrated PV systems; BIPV systems; commercialization of PV

15. NUMBER OF PAGES

16. PRICE CODE

17. SECURITY CLASSIFICATION OF REPORT

Unclassified
18. SECURITY CLASSIFICATION OF THIS PAGE Unclassified
19. SECURITY CLASSIFICATION OF ABSTRACT

Unclassified
20. LIMITATION OF ABSTRACT

UL 